\title{
Coexistence of Lobelia dortmanna and Cladium mariscus, an ecological and paleobotanical study
}

\author{
KRYSTYNA MILECKA ${ }^{1 *}$, GRZEGORZ KOWALEWSKI ${ }^{2}$, AGNIESZKA LEWANDOWSKA ${ }^{1}$, \\ WITOLD SZCZUCIŃSKI ${ }^{3}$ and TOMASZ GOSLAR ${ }^{4}$
}

\author{
${ }^{1}$ Department of Anthropocene Research, Faculty of Geographical and Geological Sciences, Adam Mickiewicz \\ University, Poznań, Poland; e-mail: milecka@amu.edu.pl \\ ${ }^{2}$ Applied Geoinformatics Laboratory, Faculty of Geographical and Geological Sciences, Adam Mickiewicz \\ University, Poznań, Poland; e-mail: ichtys@amu.edu.pl \\ ${ }^{3}$ Geohazards Research Unit, Institute of Geology, Faculty of Geographical and Geological Sciences, Adam \\ Mickiewicz University, Poznań, Poland; e-mail: witold.szczucinski@amu.edu.pl \\ ${ }^{4}$ Poznań Radiocarbon Laboratory, Faculty of Geographical and Geological Sciences, Adam Mickiewicz \\ University, Poznań, Poland; e-mail: tomasz.goslar@radiocarbon.pl
}

Received 29 October 2021; accepted for publication 10 December 2021

\begin{abstract}
Lobelia dortmanna L. (Lobeliaceae family) is an indicator species that is predominantly found in oligotrophic and acidic lakes. They are mainly distributed in northwestern Europe. Their occurrence in Poland is highly threatened by the increasing grade of human activity and environmental eutrophication; however, new sites of Lobelia were discovered in the last few decades, for example, in Lake Krzywce Wielkie situated in Bory Tucholskie National Park (BTNP), Poland. The existence of Lobelia in this lake was unexpected because Cladium mariscus was also found in the lake. Cladium has different ecological demands and is regarded as a species typical of calcareous habitats where calcium is found in abundance in the substrate. To explain the coexistence of both species in Krzywce Wielkie, pollen analysis of organic sediments was performed for four short cores collected from the littoral zone of the lake and for one long deep-water core. Additionally, macrofossil analysis was done for all the short cores. Pollen analysis revealed the existence of Cladium from the early Holocene period up to the present time. Pollen and seeds of Lobelia were found to be present since the beginning of the 20th century. Development of L. dortmanna and Myriophyllum alterniflorum populations and a decrease in the number of aquatic macrophytes in the eutrophic water indicate oligotrophication of water. This process started following the construction of drainage canal and the consequent water level decrease. This situation can be attributed to the abandonment of the agricultural areas adjoining the lake, which causes a decrease in the inflow of nutrients into the lake. Development of pine forest and establishment of BTNP enabled the protection and conservation of the surrounding catchment areas, thus restricting the potential eutrophication of the habitats.
\end{abstract}

KEYWORDS: Lobelia dortmanna, Cladium mariscus, Late Holocene, land use, trophy changes, Tuchola Forest

\section{INTRODUCTION}

Ongoing climate and environmental changes result in the shift of the geographical distribution of numerous plant and animal species (Pecl et al., 2017). However, various environmental factors, such as temperature, nutrient availability and humidity, and interactions among them (e.g., feedback effects) affect the

\footnotetext{
Corresponding author
}

nature of habitat. Therefore, the resulting response of a species to an ecological habitat may be highly variable. For instance, it was found that in lake environments an increase in water temperature may favor the growth of an ecologically dominant invasive species (Dziuba et al., 2020), whereas in other conditions, local but so far endangered species may be predominant (Kowalewski et al., 2013; Brzozowski 
et al., 2021). Several features of the habitat contribute to the type of species living in it. For instance, in a lake environment, factors like an increase in water temperature, a drop in water level (Kornijów et al., 2016), a reduction in the period of ice cover, or changes in catchment management (Poraj-Górska, 2017) may play a crucial role in determining the nature of the species living in the lake. To interpret the future response of a particular species to the ecological changes, it is beneficial to obtain the information provided in sedimentary paleorecords (Davidson et al., 2013).

Lake environments are in constant danger of undergoing rapid changes in the near future, and this situation is particularly expected to be observed in the case of lakes dominated by species that have reached the limits of their modern distribution range. A good example of such lakes is the so-called Lobelian lakes that are characterized by the presence of Lobelia dortmanna L. (Lobeliaceae family), which is an indicator species and predominantly found in oligotrophic and acidic lakes with low conductivity (Szmeja, 1997). Other species that commonly inhabit these lakes are Isoëtes lacustris, I. echinospora, Littorella uniflora and Myriophyllum alterniflorum, and these plants have similar environmental demands (Szmeja, 1992; Hannon and Gaillard, 1997; Heegaard et al., 2001). The geographical distribution of these lakes correlates with the spatial limits of the above-mentioned species. They are distributed mainly in the boreal zone of northwestern Europe (Sculthorpe, 1985; Szmeja, $2014 \mathrm{a}, \mathrm{b})$, extending further to the northern boreal zone (Moen, 1999) and eastern Lithuania (Gostyńska-Jakuszewska and Lekavičius, 1994). Thus, they occur in regions with cool and wet temperate climates, with catchments frequently dominated by pine forests (Szmeja, 2014a). In Poland, 155 Lobelian lakes were identified (Szmeja, 1997); however, only 131 of them were inhabited by populations of $L$. dortmanna, which grow in the northwestern part of the country (Szmeja et al., 1998).

Extensive studies focusing on Lobelian lakes were conducted during the second half of the 20th century (Sand-Jensen, 1978; SandJensen and Borum, 1984; Rørslett, 1991; Szmeja et al., 1998). Hence, the environmental conditions that influence the development of isoetids (Lobelia, Isoëtes, and Littorella) are well known. In addition, the structure of these specific populations was analyzed (Szmeja, 1987; Chmara et al., 2014, 2015a; Ronowski et al., 2020). However, their responses to modern land use and human activities are poorly understood, especially in the context of political changes in Central and Eastern Europe at the end of the 20th century and following the development of nature conservation measures. It turns out, in spite of many threats related to anthropogenic pressure, that many of these lake ecosystems are in good condition due to the protection provided by law and stable environmental conditions in the catchments dominated by pine forest, acidic beech forest, and peatlands (Kraska et al., 2013; Szmeja, 2014a).

Lobelian lakes constitute the most precious resource of Bory Tucholskie National Park (BTNP), which is also inhabited by lichen-rich Scotts pine forests and mires. There are six Lobelian lakes in the park (Fig. 1): Gacno Wielkie, Gacno Małe, Nierybno, Głuche, Krzywce Wielkie and Krzywce Małe, but L. dortmanna was not noticed in the last lake in recent years (Królikowska et al., 2012). The Lobelian lakes are often surrounded by patches of mires along the shore, which provide additional protection against eutrophication, as they restrict the transfer of nutrients from the catchment area (Tobolski, 2003; Szmeja, 2014a).

Krzywce Wielkie Lake has been recently included in the group of Lobelian lakes. Information regarding the development of $L$. dortmanna population in this lake was first published by Kochanowski and Tobolski (2010) and further confirmed by Kochanowska et al. (2013). This occurrence seems to be interesting because a few clusters of Cladium mariscus L. Pohl (Cyperaceae family) were also found in this lake (Herbichowa and Wołejko, 2004; Mróz, 2010). This species has quite different ecological demands and usually grows in fertile, calcareous habitats. Both L. dortmanna and C. mariscus are used as indicator species in Habitats Directive's Natura 2000 network (Council Directive 92/43/EEC). However, they are characterized by different types of habitats: code 3110 includes Lobelia lakes with Littorelletalia uniflorae and code 7210 includes calcareous fens with Cladietum marisci, Caricetum buxbaumi and Schoenetum nigricantis.

The phenomenon of the coexistence of $L$. dortmanna and C. mariscus in the same lake was studied by adopting a paleoecological 
approach, which provided useful information in a preliminary investigation carried out by Milecka and Tobolski (2015). In this study, pollen and macrofossil analyses were performed for the upper $314 \mathrm{~cm}$ of the deepwater core of sediments rich in organic matter (KW/2014) accumulated since about $2300 \mathrm{cal}$ yr BP. These analyses revealed the presence of pollen grains of Cladium but the absence of Cladium fruits and also the absence of pollen and seeds of Lobelia. Lobelia species produce small amounts of pollen that are poorly transported through the lake bottom (Milecka and Obremska, 2002), which could be the likely reason for the lack of Lobelia fossils. The quantity of Cladium pollen increased at $\sim 350 \mathrm{cal} \mathrm{yr}$ $\mathrm{BP}$ and was concurrent with the occurrence of high trophy indicators (e.g., Rumex acetosella, Plantago lanceolata, Pediastrum boryanum, P. duplex); however, at $\sim 200$ cal yr BP, water trophy decreased resulting in the development of Chara population in the lake (Milecka and Tobolski, 2015). All these findings help to draw clear conclusions regarding the emergence of the Lobelia population and the duration of the coexistence between Lobelia and Cladium. Moreover, some questions also arise: (1) From when did Lobelia and Cladium start to occur together in the lake? (2) What conditions influenced their presence and what was the reason for the recent spread of Lobelia? (3) How did land use, human pressure and protection by law influence this recent spread? (4) What are the general conditions for the modern existence of Lobelian lakes and what may be their future?

To trace the development of the recent population of Lobelia in Lake Krzywce Wielkie, a detailed paleoecological analysis of the lake's sediments was conducted. The evaluation was based mainly on high-resolution pollen records and macrofossil analyses of ${ }^{14} \mathrm{C}-,{ }^{210} \mathrm{~Pb}$ - and ${ }^{137} \mathrm{Cs}$-dated sediment cores, and was supplemented with the analysis of old maps that show the hydrological and land-use changes during the last 200 years, prepared by Nienartowicz (2012). To determine the initial existence of Lobelia populations in Lake Krzywce Wielkie, four cores of sediments from the littoral zone of the lake were taken. To trace the development of Cladium and Lobelia populations, the pollen analysis of the older part of the long core from the central part of the lake (KW/2014) was done.

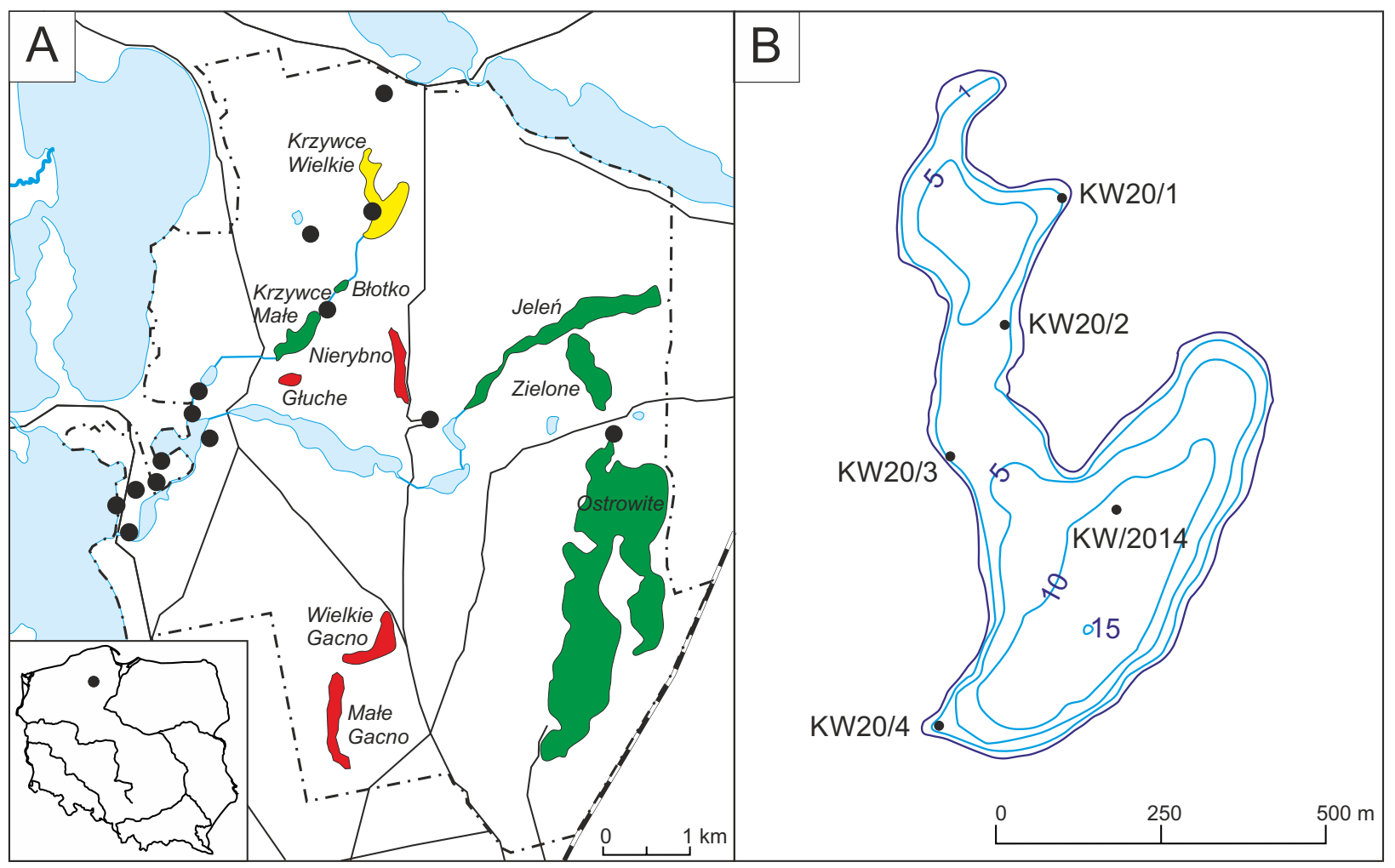

Fig. 1. Study area. A - location of lake Krzywce Wielkie in BTNP. Inset map shows location in Poland. Dot-dashed line border of BTNP, black circle - fossil site of Cladium mariscus according to Gałka and Tobolski (2006), yellow lake - sites of Lobelia dortmanna and C. mariscus, red lakes - sites of L. dortmanna, green lakes - site of C. mariscus; $\mathbf{B}-$ locations of sediment cores in Lake Krzywce Wielkie. Isobaths after Błoniarz et al. (2016) in metres 


\section{STUDY AREA}

Tuchola Forest is a large forest located on an outwash plain formed during the last glaciation (Dysarz, 1998; Kowalewski, 2002). Woś (1999) defined the modern climate of the region as temperate, cool and wet. The mean temperature in January is $-3.2^{\circ} \mathrm{C}$ and in July it is $19^{\circ} \mathrm{C}$, the annual average rainfall is $573 \mathrm{~mm}$, and the vegetative period lasts of 180-200 days.

BTNP (Fig. 1), established in 1996, is located adjacent to the previously established five landscape parks covering the entire area of Tuchola Forest. The area of BTNP is about 5000 ha, which comprises only a small portion of the whole complex. The park is almost completely covered by dry and fresh pine forest communities with many lakes (Tobolski, 1998; Matuszkiewicz et al., 2012). Lake Krzywce Wielkie is located in the northern part of BTNP. Its surface area is 25 ha, has a maximum depth of $15.1 \mathrm{~m}$ and a mean depth of $9.0 \mathrm{~m}$ (Błoniarz et al.,2016). Direct catchment of this endorheic lake is $1624 \mathrm{~km}^{2}$ (Bajkiewicz-Grabowska, 2004). The poor sandy soils and prevailing pine forest cover of the catchment limit the supply of nutrients to the lake (Bajkiewicz-Grabowska, 2004).

In BTNP, two water courses connect some lakes (Fig. 1): the stream Struga Siedmiu Jezior and an artificial canal called KrzywceBłotko. C. mariscus is found in three lakes located along the upper course of Struga Siedmiu Jezior (Solon and Matuszkiewicz, 2012); however, fossil macroremains were found in recent sediments along the whole course of this stream (Gałka and Tobolski, 2006). The growth of Lobelia was detected in some endorheic lakes of the central part of BTNP and in the Krzywce-Błotko canal. Both species cooccur only in Krzywce Wielkie, along the western and eastern shores of the lake. The coexistence of $C$. mariscus and $L$. dortmanna was also documented in three lakes of Tuchola Forest (outside of BTNP): Nawionek, Głuche and an unnamed one in West Pomerania (Milecka, 2005; Kochanowska et al., 2013).

L. dortmanna, M. alterniflorum, and Juncus bulbosus were identified in Krzywce Wielkie during the botanical analysis of two cross-sections traversing the eastern part of the lake (Bociąg, 2011). Polygonum amphibium and Potamogeton natans were also recorded. That research was conducted to monitor the protection efficiency of the park in retaining the natural ecosystem. Lobelia occurred down to $1 \mathrm{~m}$ of water depth. The patches of $M$. alterniflorum were abundant and clear down to $4 \mathrm{~m}$ of water depth. C. mariscus, Typha angustifolia, and Carex species developed along the lake shores.

\section{METHODS}

\section{FIELD WORK AND SAMPLING}

On May 18, 2020, four cores (KW20/1, KW20/2, KW20/3 and KW20/4) of sediments rich in organic matter were collected from the littoral zone of Lake Krzywce Wielkie using a gravity corer (UWITEC Co., Austria). The inner diameter of the corer liner was $86 \mathrm{~mm}$. The cores were sampled in the laboratory of the Faculty of Geographical and Geological Sciences, Adam Mickiewicz University, Poznan. The uppermost layers of the sediments $(1-10 \mathrm{~cm})$, characterized by high water content, were sectioned in 2 -cm-thick intervals in order to ensure that sufficient volume of the sediment is sampled for macrofossil analysis and dating. The deeper parts $(10-35 \mathrm{~cm})$ were sliced into 1-cm-thick samples. Each sediment sample was further subsampled for pollen analysis $\left(1 \mathrm{~cm}^{3}\right)$, macrofossil analysis and radiometric dating. The long core (624 cm, KW/2014) was drilled in 2014 from a deeper central part of the lake for paleobotanical analysis (Fig. 1). The upper half $(314 \mathrm{~cm})$ of the sediment was analyzed and discussed by Milecka and Tobolski (2015), while the lower half $(310 \mathrm{~cm})$ was investigated in this work. The samples were taken at 4 -cm-thick intervals.

\section{CHRONOLOGY}

$$
{ }^{14} \mathrm{C} \text { dating }
$$

Fifteen organic samples, each taken at $20 \mathrm{~cm}$ intervals in $1 \mathrm{~cm}$ slices from the lower part of the core KW/2014, were transported to Poznań Radiocarbon Laboratory for ${ }^{14} \mathrm{C}$ dating using the AMS technique (Goslar et al., 2004). Most of the samples were macrofossils of terrestrial plants (Pinus needles, bud scales and Betula fruits, bud scales), but sediments from the deepest part contained few terrestrial macrofossils, and hence bulk sediment sample was taken from this area.

\section{${ }^{210} \mathrm{~Pb}$ and ${ }^{137} \mathrm{Cs}$ dating}

The age models for the cores collected from the recently formed lake sediments (deposited during the past century) of the littoral zone were constructed using ${ }^{210} \mathrm{~Pb}$ and ${ }^{137} \mathrm{Cs}$ radioisotopes. ${ }^{210} \mathrm{~Pb}$ is a natural radioisotope formed in the course of the decay of ${ }^{238} \mathrm{U}$ and has a half-life of 22.3 years. In sediments, total ${ }^{210} \mathrm{~Pb}$ is the sum of the so-called supported ${ }^{210} \mathrm{~Pb}$ $\left({ }^{210} \mathrm{~Pb}_{\text {sup }}\right)$, which is continuously produced by the decay of parent isotopes, and excess ${ }^{210} \mathrm{~Pb}\left({ }^{210} \mathrm{~Pb}_{\mathrm{ex}}\right)$, delivered to the sediment surface mainly by atmospheric 
deposition. Along with the continuous accumulation of the deposits, the activity of ${ }^{210} \mathrm{~Pb}_{\text {ex }}$ decreases with depth due to its decay and provides a tool for the assessment of sediment age using models based on various assumptions (Appleby and Oldfield, 1992; Sanchez-Cabeza and Ruiz-Fernández, 2012). The artificial ${ }^{137} \mathrm{Cs}$ was first introduced into the environment in measurable amounts in the early 1950 s. It showed maximum activity in 1963 in relation to numerous nuclear bomb tests and also in 1986 related to the Chernobyl event (Ritchie and McHenry, 1990).

The ${ }^{137} \mathrm{Cs}$ and ${ }^{210} \mathrm{~Pb}$ activities were measured using gamma spectrometry at the Institute of Geology, Adam Mickiewicz University, Poznań, Poland (Szczuciński et al., submitted). The 2 -cm-thick sediment core samples were dried and homogenized. The activities of ${ }^{137} \mathrm{Cs},{ }^{210} \mathrm{~Pb},{ }^{214} \mathrm{~Pb}$ and ${ }^{214} \mathrm{Bi}$ were measured for 50-70 hours using a high-purity coaxial wideenergy germanium detector (Canberra BE3830) with a remote detector chamber option set for low-energy background reduction. The average of ${ }^{214} \mathrm{~Pb}$ and ${ }^{214} \mathrm{Bi}$ activities, which are in radioactive equilibrium with ${ }^{226} \mathrm{Ra}$, was used as a measure to determine the concentration of ${ }^{210} \mathrm{~Pb}_{\text {sup }}$. The ${ }^{210} \mathrm{~Pb}_{\text {ex }}$ value was calculated as the difference between the measured total ${ }^{210} \mathrm{~Pb}$ and ${ }^{210} \mathrm{~Pb}_{\text {sup }}$. The obtained analytical results were used to develop an age model for the sediments deposited during the last century using the serac package (Bruel and Sabatier, 2020). Constant flux constant sedimentation rate (CFCS) and constant initial concentration models were established and verified based on ${ }^{137} \mathrm{Cs}$ activity profiles. The results revealing very low ${ }^{210} \mathrm{~Pb}_{\mathrm{ex}}$ activities, much smaller than the activity obtained using 2-sigma accuracy tests, were not taken into consideration for the age model computation.

\section{POLLEN ANALYSIS}

Pollen analysis was done for every sample collected from four short cores, that is, 30 samples per core, and for 78 samples obtained from the long core KW/2014. The procedure for laboratory preparation followed that described by Berglund and Ralska-Jasiewiczowa (1986). Mineral particles were removed by HF, and organic compounds by $\mathrm{KOH}$. Acetolysis was performed for 3 minutes. Prior to the preparation of pollen slides, samples were stained with safranine. Samples taken from core KW/2014 were counted to at least 700 pollen grains of trees and shrubs. The analysis of the sediments of the littoral cores revealed lower pollen frequencies than observed in more consolidated sediments from the deeper part of the lake. Hence, the sum of the pollen grains was not very high, exceeding 400 pollen grains of trees and shrubs in almost all spectra. The sum of AP (trees and shrubs) and herbs (NAP) was the basis for percentage calculations (calculation sum). Aquatics, telmatophytes, and selected nonpollen palynomorphs (NPPs) were also counted; however, they were not included in the calculation sum. The pollen diagrams were initially compiled using Tilia and Tilia Graph programs (Grimm, 1992) and later improved using CorelDraw X16 software.

Particular attention was given to the identification of the pollen of Lobelia and Cladium, which is the main objective of our research. Every pollen slide was examined in detail, regardless of the pollen sum, to find their grains. The pollen types of both species were identified according to Beug (2004). Every pollen grain type of Lobelia species was carefully examined, because there are some similar types of pollen, for example, Linaria, Digitalis and Verbascum. The determination of Cladium pollen was not simple either because some of them do not have an elongated ending, which is a critical feature for reliable classification. However, regular presence of Cladium in the samples allowed for the detailed observation and recognition of some additional indicator features, which include regular conical shape, relatively big size, very gentle, circular perforations at $1 / 3$ of the grain length, and very clear perforation at the base of the cone. Pollen grains "cf. Cladium" were not classified as "Cladium" if the analyzed grains were partially destroyed or crushed and the perfect observation of all the indicator features was not possible.

\section{MACROFOSSIL ANALYSIS}

Macrofossil analysis was conducted for sediment slices with a volume of $60 \mathrm{~cm}^{3}$ and collected from a depth of 1-10 cm and also for slices with a volume of $30 \mathrm{~cm}^{3}$ taken from 11-35 $\mathrm{cm}$. The samples were washed with water and sieved using a mesh size of $0.125 \mathrm{~mm}$. The residue was examined under a stereomicroscope (Nikon, Japan) at 10×, 40×, and $100 \times$ magnifications. The results were presented in the diagrams of absolute frequency prepared in $\mathrm{R}$ ( $\mathrm{R}$ Core Team, 2020) in "rioja" package (Juggins, 2020) and modified in CorelDraw X16.

\section{RESULTS}

The results showed that the long core $\mathrm{KW} / 2014$, drilled at the water depth of $546 \mathrm{~cm}$, is composed of gray and fine detritus gyttja (314-604 cm of sediment depth) with increased content of mineral particles in the bottom part $(604-624 \mathrm{~cm})$.

The four short sediment cores collected from the littoral zone of Lake Krzywce Wielkie showed very similar lithological features at the depth of 40-50 $\mathrm{cm}$ from the water surface (Fig. 1, Table 1). The samples are composed of dark brown detritus gyttja with decreasing content of mineral particles toward the upper part.

Table 1. The location of coring sites (Fig. 1)

\begin{tabular}{l|c|c}
\hline \hline Name of core & Longitude & Latitude \\
\hline KW/2014 & $17^{\circ} 33^{\prime} 40.18^{\prime \prime} \mathrm{E}$ & $53^{\circ} 50^{\prime} 21.55^{\prime \prime} \mathrm{N}$ \\
KW20/1 & $17^{\circ} 33^{\prime} 35.86^{\prime \prime} \mathrm{E}$ & $53^{\circ} 50^{\prime} 37.36^{\prime \prime} \mathrm{N}$ \\
KW20/2 & $17^{\circ} 33^{\prime} 30.85^{\prime \prime} \mathrm{E}$ & $53^{\circ} 50^{\prime} 30.91^{\prime \prime} \mathrm{N}$ \\
KW20/3 & $17^{\circ} 33^{\prime} 26.22^{\prime \prime} \mathrm{E}$ & $53^{\circ} 50^{\prime} 24.29^{\prime \prime} \mathrm{N}$ \\
KW20/4 & $17^{\circ} 33^{\prime} 25.18^{\prime \prime} \mathrm{E}$ & $53^{\circ} 50^{\prime} 10.55^{\prime \prime} \mathrm{N}$ \\
\hline
\end{tabular}




\section{${ }^{14} \mathrm{C}$ DATING}

The ${ }^{14} \mathrm{C}$ ages of samples taken from the core KW/2014 (Table 2) were calibrated against the curve INTCAL20 (Reimer et al., 2020), and were used to build an age-depth model using a free shape algorithm (Goslar et al., 2009). For the development of models, the set of calibrated ${ }^{14} \mathrm{C}$ dates was supplemented with the calendar date that marked the beginning of Holocene (11,550 cal BP, according to the increase of birch and decrease of juniper trees

Table $2 .{ }^{14} \mathrm{C}$ ages of samples from the core KW/2014

\begin{tabular}{l|c|c|c|c}
\hline \hline $\begin{array}{l}\text { Depth } \\
{[\mathrm{cm}]}\end{array}$ & Material & $\begin{array}{c}\text { Lab no. } \\
\text { Poz- }\end{array}$ & $\begin{array}{c}\text { Age }{ }^{14} \mathrm{C} \\
(\mathrm{BP})\end{array}$ & $\begin{array}{c}\text { Modeled date } \\
(68.2 \% \text { conf. } \\
\text { interval, cal BP })\end{array}$ \\
\hline 314 & Plant remains & 126617 & $2415 \pm 35$ & $2490-2375$ \\
334 & Plant remains & 126618 & $2570 \pm 40$ & $2760-2705$ \\
354 & Plant remains & 126619 & $2875 \pm 35$ & $3060-2960$ \\
374 & Plant remains & 126621 & $3055 \pm 30$ & $3340-3230$ \\
394 & Plant remains & 126622 & $3385 \pm 35$ & $3680-3575$ \\
414 & Plant remains & 126623 & $3565 \pm 35$ & $3920-3835$ \\
434 & Plant remains & 126624 & $3770 \pm 35$ & $4220-4090$ \\
456 & Plant remains & 126625 & $3925 \pm 30$ & $4420-4310$ \\
476 & Plant remains & 126626 & $4165 \pm 35$ & $4825-4650$ \\
494 & Plant remains & 126627 & $4520 \pm 40$ & $5175-5055$ \\
514 & Plant remains & 126628 & $4610 \pm 35$ & $5450-5315$ \\
538 & Plant remains & 126629 & $5570 \pm 40$ & $6385-6310$ \\
562 & Plant remains & 126631 & $6480 \pm 35$ & $7400-7335$ \\
586 & Plant remains & 126632 & $9090 \pm 50$ & $10270-10200$ \\
620 & Bulk sediment & 126633 & $11110 \pm 60$ & $13095-12935$ \\
\hline
\end{tabular}

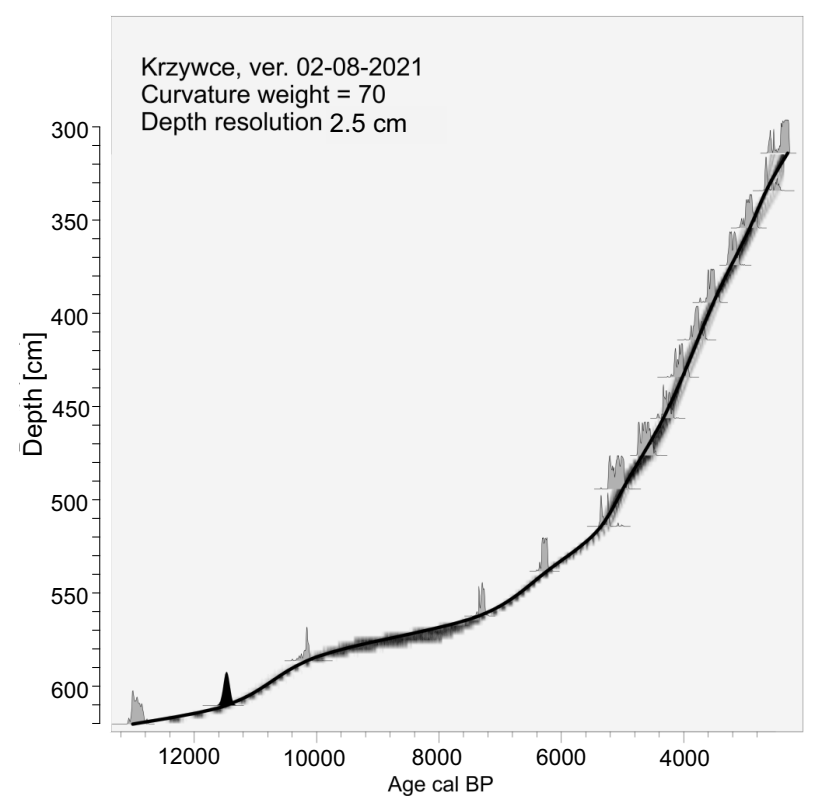

Fig. 2. Age-depth model of the lower part of profile KW/2014. Gray silhouettes represent calibrated dates of the samples analyzed with ${ }^{14} \mathrm{C}$. Black silhouette represents the date of the beginning of Holocene
(Milecka, 2005; Filbrandt-Czaja, 2009), which has been clearly indicated in the pollen profile at the depth of $610 \mathrm{~cm}$. The age-depth model (Fig. 2) indicates a rather slow (and variable) accumulation rate in the lower part of the profile (until $\sim 6000 \mathrm{BP}$ ) and a distinctly faster (and almost constant) accumulation rate in the upper part (until $\sim 2500 \mathrm{BP}$ ). It has to be considered, however, that the ${ }^{14} \mathrm{C}$ age of the lowermost sample (at $620 \mathrm{~cm}$ ) might be influenced by the reservoir effect of unknown magnitude, therefore the uncertainty of dates at the lowest $30 \mathrm{~cm}$ of the profile may be greater than that calculated using the algorithm.

\section{${ }^{210} \mathrm{~PB}$ AND ${ }^{137} \mathrm{CS}$ DATING}

The vertical distribution of ${ }^{210} \mathrm{~Pb}_{\mathrm{ex}}$ and ${ }^{137} \mathrm{Cs}$ activities is presented in Fig. 3, while the complete dataset is available in the supplementary material (Supplementary file $\mathbf{1}^{1}$ ). The total ${ }^{210} \mathrm{~Pb}$ and ${ }^{210} \mathrm{~Pb}_{\text {ex }}$ content was generally characterized by a downward decrease, although with some irregularities. The latter was likely due to sediment mixing. The sediment accumulation rates for the last century according to the CFCS model (Fig. 3) were as follows: $1.64 \pm 0.36 \mathrm{~mm} /$ $\mathrm{yr}$ in core $\mathrm{KW} 20 / 1,1.05 \pm 0.19 \mathrm{~mm} / \mathrm{yr}$ in core $\mathrm{KW} 20 / 2,1.06 \pm 0.09 \mathrm{~mm} / \mathrm{yr}$ in core KW20/3, and $1.38 \pm 0.30 \mathrm{~mm} / \mathrm{yr}$ in core KW20/4.

The ${ }^{137} \mathrm{Cs}$ activity profiles (Fig. 3) showed maximum values in the near-surface sediments, decreasing with the sediment depth and reaching very low activities in the lower parts of the investigated cores. Such ${ }^{137}$ Cs profiles often result from postdepositional remobilization of the isotope, both upward and downward, as previously documented in the littoral zones of other lakes and lagoons (Foster et al., 2006; Woszczyk et al., 2017; Brzozowski et al., 2021). However, taking into account the ${ }^{210} \mathrm{~Pb}-$ based sediment accumulation rates, the calculated sediment depths, dated to the early 1950s AD (Fig. 3), correspond to a decrease in ${ }^{137} \mathrm{Cs}$ activities to values below $20 \mathrm{mBq} / \mathrm{g}$. As a consequence, generally, the presence of moderate-to-high ${ }^{137} \mathrm{Cs}$ activities in the sediments dated post-1950s AD suggests that the

\footnotetext{
1 Supplementary file radionuclides in KW20 cores. Results of the radionuclide analysis of sediment cores. The tables include the analytical data (lab no, sampling depth intervals, ${ }^{137} \mathrm{Cs}$, total ${ }^{210} \mathrm{~Pb}$, supported ${ }^{210} \mathrm{~Pb}$, excess ${ }^{210} \mathrm{~Pb},{ }^{40} \mathrm{~K},{ }^{232} \mathrm{Th},{ }^{238} \mathrm{U}$ activities, and the respective 2-sigma measurement uncertainties) and metadata (coring year, geographical coordinates, laboratory name, instrument type, measurement start and end dates)
} 

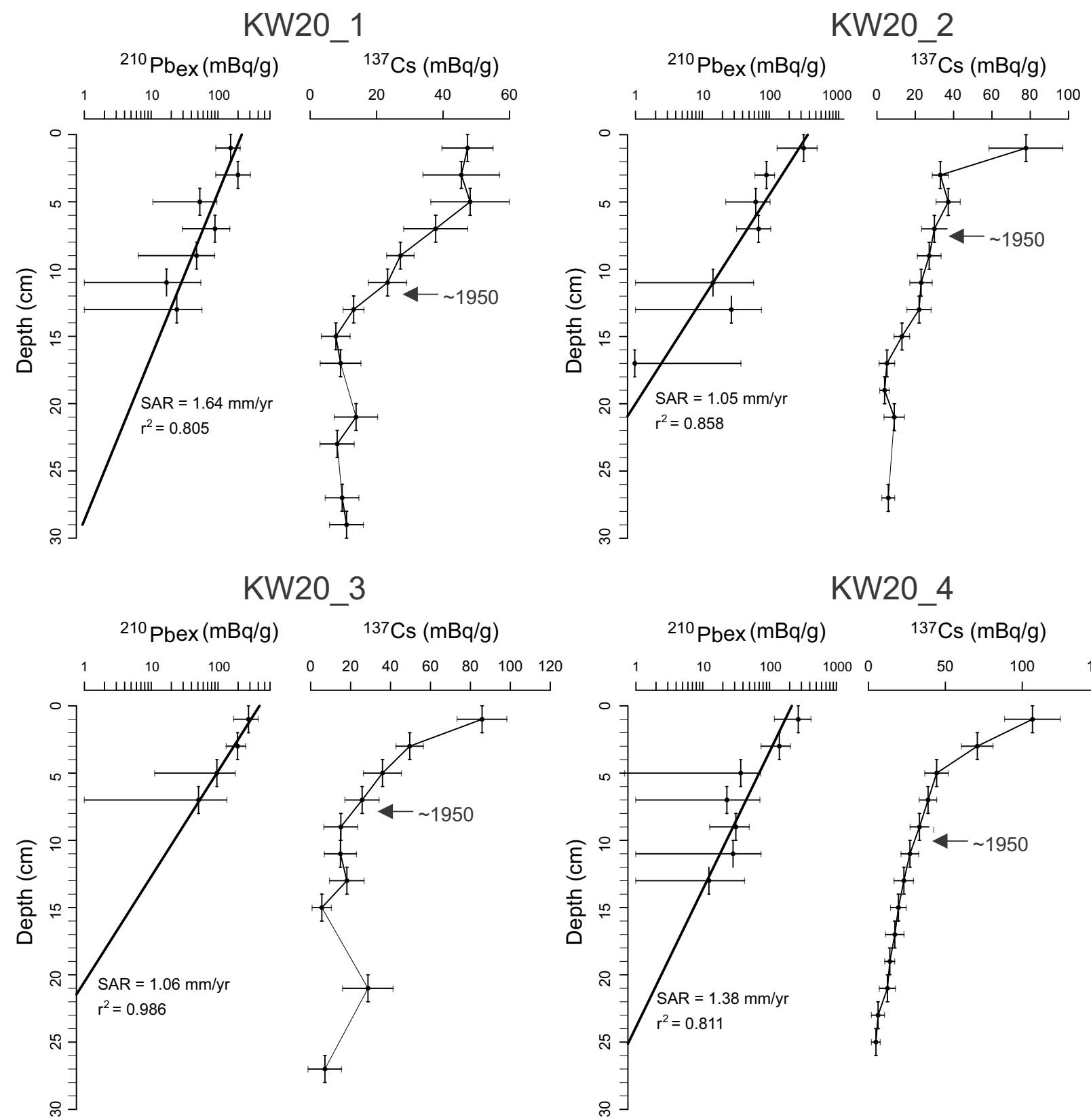

KW20_3
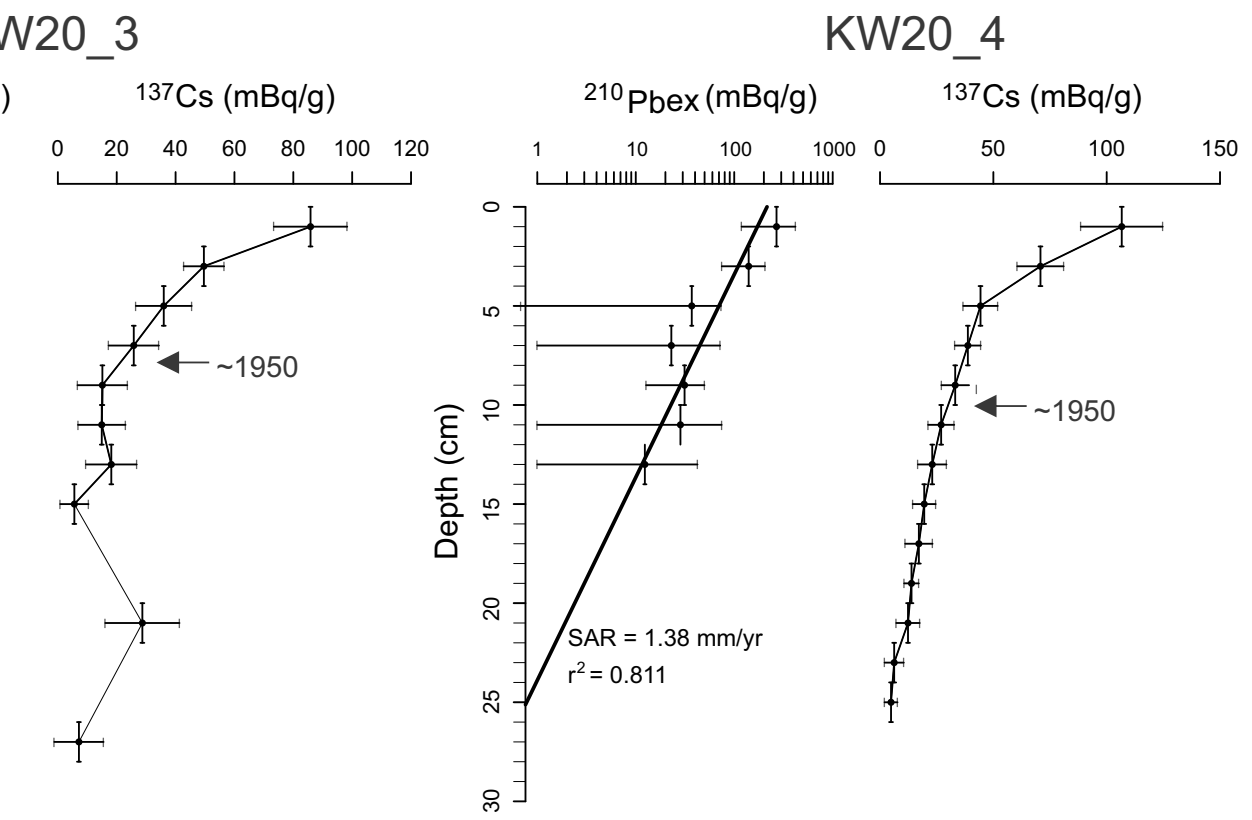

Fig. 3. Short-lived radionuclide $\left({ }^{210} \mathrm{~Pb}\right.$ ex nd $\left.{ }^{137} \mathrm{Cs}\right)$ measurements in cores KW20_1, KW20_2, KW20_3 and KW20_4. ${ }^{210} \mathrm{~Pb}$ ex activities are presented as semilogarithmic plots, the trend line was used for sediment accumulation rate (SAR) calculation using constant flux constant sedimentation rate model. The sediment depth of ${ }^{210} \mathrm{~Pb}$-based age of $1950 \mathrm{AD}$ is marked on ${ }^{137} \mathrm{Cs}$ activity profile. The vertical error bars refer to analyzed sediment sample thickness, while the horizontal bars depict 2-sigma uncertainty. The plots were obtained using serac (Bruel and Sabatier, 2020)

${ }^{210} \mathrm{~Pb}$-based age model is generally accurate. The comparison of the CFCS and CIC models with ${ }^{137} \mathrm{Cs}$ profiles is presented in supplementary files (Supplementary file $2^{2}$ ). Since the cores show the evidence of sediment mixing, the sediment accumulation rates and consequently the calculated ages indicate approximate values only.

2 Supplementary file 2. Age scale to the CFCS and CIC models KW20_1-KW20_4

\section{POLLEN AND MACROFOSSIL ANALYSES}

\section{Core KW/2014}

The sediment core from the deepest part of the lake demonstrates the occurrence of vegetation changes from the end of the Late Glacial period to $\sim 2300$ cal yr BP (Fig. 4). The upper part of this core (2300 BP to the present) was studied by Milecka and Tobolski (2015). As the main objective of this paper was to trace the history and development of Cladium and Lobelia populations, only selected results relevant 


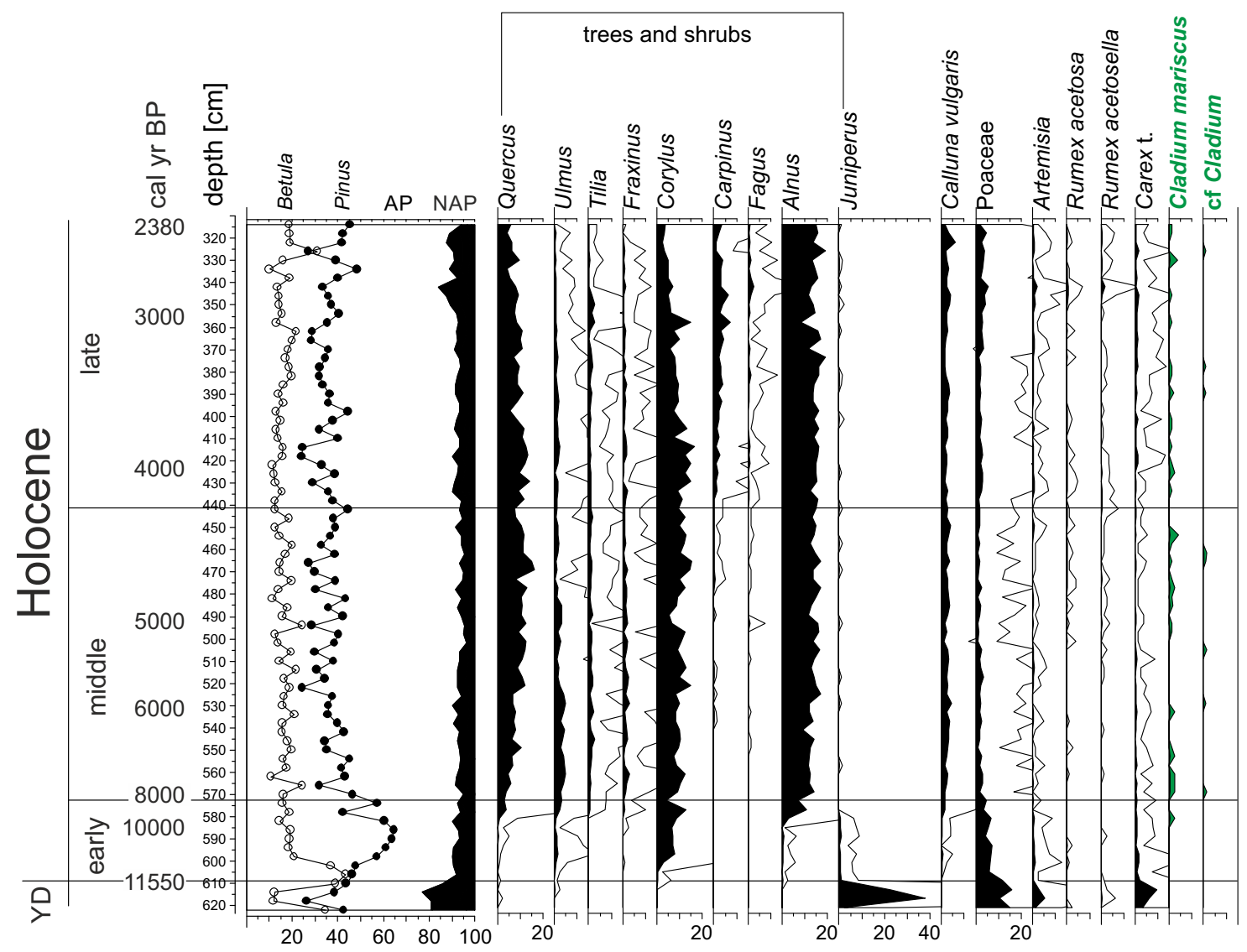

Fig. 4. Pollen diagram of core KW/2014, selected percentage curves (in black). Exaggerations $\times 10$ are given for better observation of rare types. Division of the Holocene after Walker et al. (2012)

for the reconstruction of the local environment are presented.

The oldest part, deposited during the Late Glacial period, contains pollen typical for open tundra and steppe-like vegetation with clusters of Juniperus. The beginning of the Holocene (11,550 cal yrs BP, Fig. 4) was marked by the disappearance of cold-demanding tundra species (Juniperus) and an increase of Betula. The phase of birch-pine forest lasted to 11,000 cal yrs BP, and was subsequently overtaken by the pine-birch forest, until the spread of deciduous forest (Quercus, Ulmus, Tilia, Fraxinus) at $\sim 9850$ cal yrs BP. During the middle part of the Holocene, approximately between 8200 and 4150 cal yrs BP, deciduous forest prevailed, as suggested by the presence of numerous pollen grains of Quercus, Ulmus, and Corylus. The record of the older part of the late Holocene approximately between 4150 and 2380 cal yrs BP, showed the presence of a forest cover, but the proportion of Ulmus, Tilia, and Fraxinus decreased, paving the way for the development of Carpinus. Pine forests with juniper and heather continued to be present. In the youngest layers of the sediments, the proportion of the pollen of light-demanding plants increased, which included members of the Poaceae family, Artemisia sp., Rumex sp. and Carex sp. This could be the result of occasional human activity in the Tuchola Forest.

The investigation of younger sediments of the late Holocene, as reported by Milecka and Tobolski (2015), revealed continued forest cover in the areas adjacent to Lake Krzywce Wielkie. Pine trees with a minor proportion of deciduous trees were found, and Carpinus played an important role from 1800 to 750 BP. Later, Pinus became dominant, and some human activity indicators appeared (Milecka and Tobolski, 2015).

\section{L. dortmanna and C. mariscus in the core KW/2014}

The pollen of Lobelia was not found in this core. Pollen grains of $C$. mariscus were found regularly from the depth of $579 \mathrm{~cm}(\sim 9560 \mathrm{cal}$ yr BP) to the uppermost layers (2380 cal yr $\mathrm{BP})$, except for the climatic optimum period (5740-5235 cal yr BP). The pollen was also regularly identified in the youngest part of this 
core, analyzed earlier by Milecka and Tobolski (2015). Stable and consistent occurrence of the pollen of $C$. mariscus through the entire Holocene indicates that this plant was present continuously in the reed beds of Lake Krzywce Wielkie.

\section{Littoral cores (KW20/1-KW20/4)}

The cores KW20/1 - KW20/4 (Figs 5A, B and 6) show 200 years of sediment accumulation and development of vegetation in the lake and in the catchment. This is confirmed by similar time and pattern of the accumulation of sediments indicated by isotope dates and the general picture of vegetation succession in Tuchola Forest during the last centuries. Regional plant communities were dominated by pine forest and a low proportion of deciduous species, such as Quercus, Carpinus, Corylus, Alnus and Populus. They likely occurred as mixtures in some patches of forest and reflect the complex mosaic of habitats at these sites. The dominance of Pinus decreased slowly with time (Fig. 5A, B). In contrast, the proportion of herbs, especially grasses, increased. During the last 100 years, higher proportion of Juniperus was also documented, accompanied by a declining contribution of deciduous species like Quercus, Carpinus and Corylus. Percentages below $1 \%$ of the calculation sum for these species indicate their possible disappearance in the areas directly adjacent to the lake; pollen grains were blown from distant places (Milecka et al., 2004; Miotk-Szpiganowicz et al., 2004; Ralska-Jasiewiczowa et al., 2004).

\section{KW20/1}

Cladium pollen was present in almost all the spectra of the entire core. Moreover, single fruits were found in the middle part of the core, which indicate that Cladium was likely present in this part of the lake for over 200 years. It was a regular constituent of reed bed communities, along with Carex, Schoenoplectus, Typha latifolia and probably Phragmites australis (common species at present). The presence of Schoenoplectus and Typha is confirmed by the presence of their fruits revealed by the macrofossil analysis (not identified to species level). The investigations also revealed the presence of another species that is predominantly found in high reed bed, Eleocharis palustris. Frequent occurrence of pollen grains and fruits of Carex species suggests that they are common inhabitants of low reed bed communities.

Pollen grains of Lobelia were found in samples taken from the depth of $14 \mathrm{~cm}$ in the sediment toward the upper layers. There were singular grains in a few samples, despite the fact that the core was collected from the area right next to the location where the modern population of Lobelia was found. Seeds of Lobelia were found in the samples at the sediment depth of 8 and $10 \mathrm{~cm}$. The presence of Lobelia pollen in the sample at the depth of $14 \mathrm{~cm}$ indicates that the population must have developed before $1935 \mathrm{AD}$.

Myriophyllum alterniflorum is a common component of aquatic plants in the upper part of the core. Its pollen grains were found in all the samples taken from the depth of $11 \mathrm{~cm}$ upward, with the maximum content being $2 \%$. Moreover, single pollen grains were found at the depth of 14 and $23 \mathrm{~cm}$. Fruits of Myriophyllum sp. were found at the depths of 10 , 12 and $14 \mathrm{~cm}$ in the sediment. Taking into account the exact identification of pollen and the modern presence of $M$. alterniflorum in the lake, the fruits very likely belong to this species. Fruits of Potamogeton (6-28 cm, up to 9 specimens) and Chara oospores $(2-29 \mathrm{~cm}$, up to 219 specimens) were the most abundant in the macrofossil group. The relatively high numbers of subfossil Potamogeton fruits and Chara oospores suggest their local occurrence.

\section{KW20/2}

Pollen of Cladium were found in many samples throughout the core; however, they occurred mostly as single grains. Subfossil fruits of Cladium were found at the depths of 2, 6 and $12 \mathrm{~cm}$. Few fruits of other reed bed plants were also identified, for example, Typha sp. (at the depth of 6-22 cm) and E. palustris $(32 \mathrm{~cm})$. Low reed bed plants were relatively abundant, which comprised Carex fruits, $P$. amphibium, Ranunculus sceleratus, and $J$. bulbosus.

A single pollen grain of $L$. dortmanna was found at the depth of $14 \mathrm{~cm}$. The seeds were found at 10-13 cm. Thus, according to the fossil record, Lobelia was present in this part from the turn of the 19th and 20th centuries.

Among the aquatic macrophytes, Potamogeton (3-33 cm, 1-4 specimens) and Chara sp. (2-31 cm, 1-1090 specimens) were the most abundant. Pollen of $M$. alterniflorum occurred 


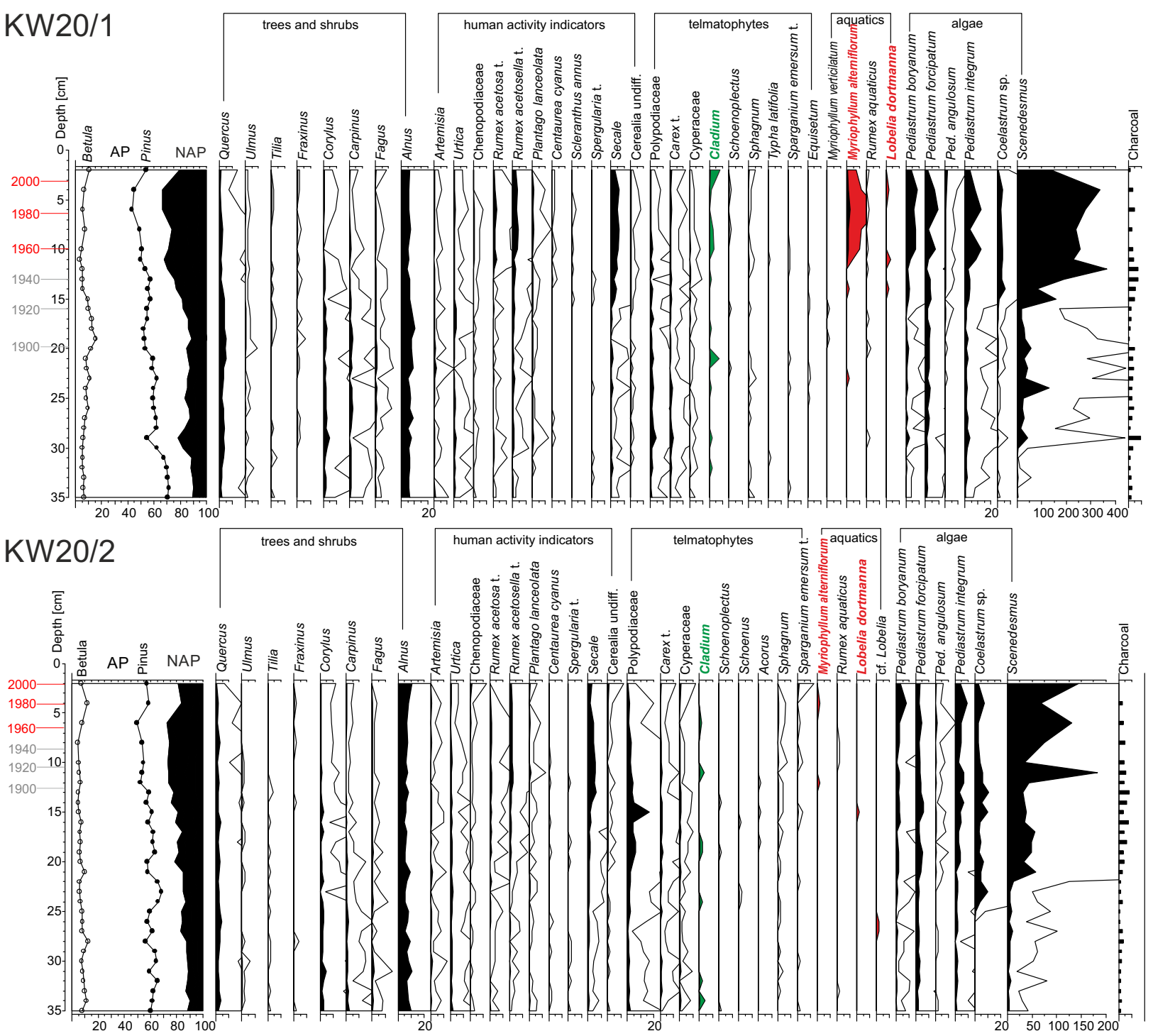

Fig. 5A. Pollen diagrams of cores KW20/1 - KW20/2. Selected percentage curves of trees and shrubs, human indicators and pollen of local plant communities. Curve units $-10 \%$ unless otherwise stated. Red dates - dates derived from the ${ }^{210} \mathrm{~Pb}-\mathrm{based}$ age model, gray dates - linear approximation of the model assuming constant accumulation rate

at the depths of 4 and $12 \mathrm{~cm}$. The existence of Myriophyllum fruits (at 4, 6 and $17 \mathrm{~cm}$ ), despite low fruit production by this plant, suggests the in situ presence of this species (M. alterniflorum).

\section{KW20/3}

Pollen grains of Cladium and cf. Cladium were found in the lower part of the core, up to $18 \mathrm{~cm}$, and in the uppermost layers of the sediments. Singular seeds of this species were identified at the depths of 10,14 and $25 \mathrm{~cm}$, and more numerous, up to 12 specimens per sample, were found at the depths of 2 and $4 \mathrm{~cm}$. Thus, the fossil records suggest almost continuous presence of this species. They were accompanied by other species of high reed beds as indicated by the seeds and pollen of
Schoenoplectus lacustris, and seeds of Typha sp. and Eloecharis. Low reed beds are represented by pollen of the Cyperaceae family, Carex sp., Thelypteris palustris, Hottonia, Iris pseudoacorus, and seeds of J. bulbosus, $P$. amphibium and $R$. sceleratus.

Pollen of Lobelia was not found in the core KW20/3. However, singular seeds of Lobelia occurred at sediment depths of 6, 8, 10, 12 and $22 \mathrm{~cm}$. During the macrofossil analysis, numerous seeds of Potamogeton (3-33 cm, 1-12 specimens) and some seeds of Myriophyllum sp. $(6,8,20$ and $22 \mathrm{~cm}$, singular specimen) and Najas marina were identified. Singular pollen of Potamogeton and M. alterniflorum were identified at $12 \mathrm{~cm}$. Utricularia $(8 \mathrm{~cm})$ and Rumex aquaticus $(4 \mathrm{~cm})$ were also found as single pollen. At the depth interval of 1-13 cm, Chara 


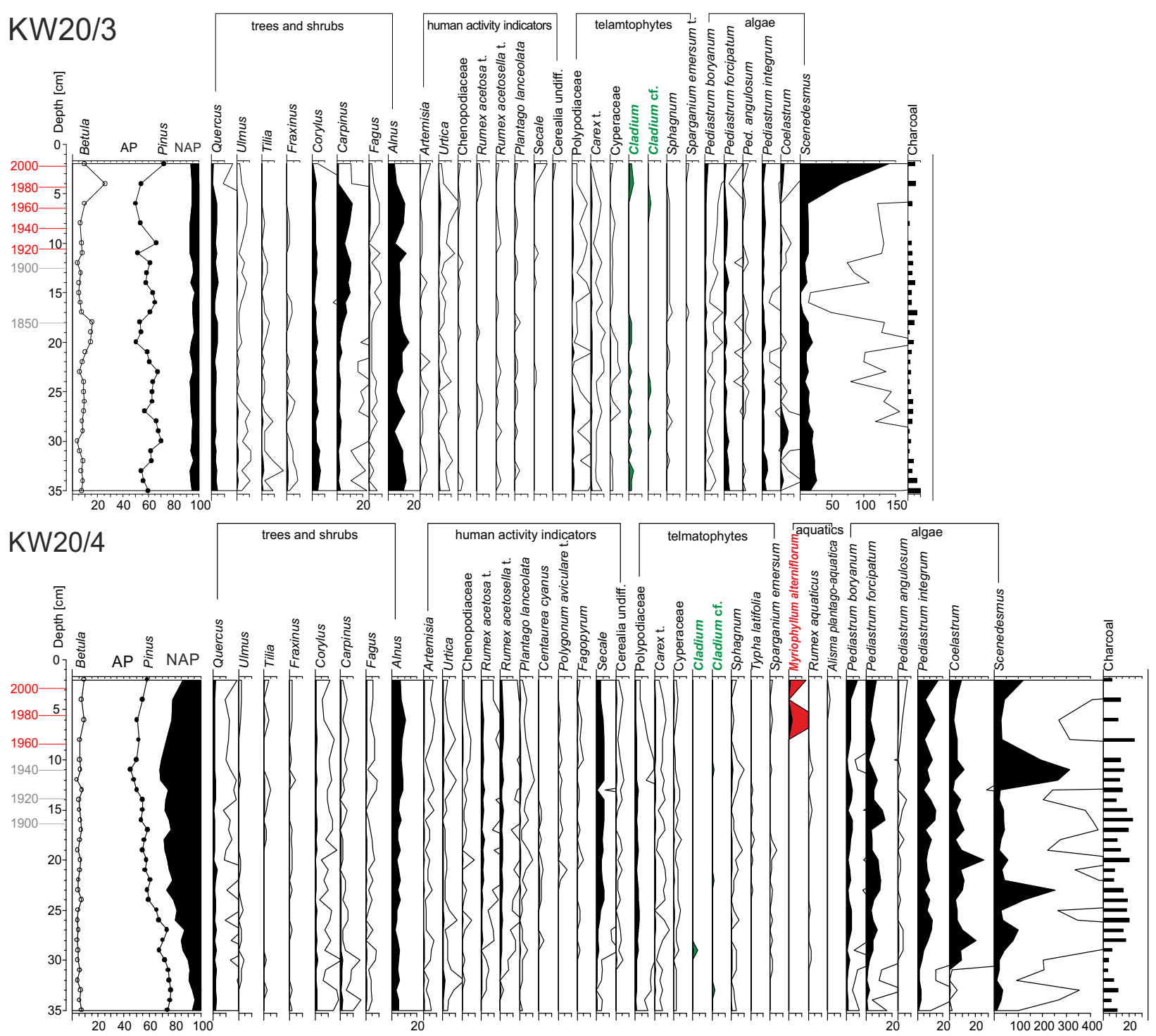

Fig. 5B. Pollen diagrams of cores KW20/3 - KW20/4. Selected percentage curves of trees and shrubs, human indicators and pollen of local plant communities. Curve units $-10 \%$ unless otherwise stated. Red dates - dates derived from the ${ }^{210} \mathrm{~Pb}-\mathrm{based}$ age model, gray dates - linear approximation of the model assuming constant accumulation rate

oospores (1-35) were found in the sediments. The consistent presence of Potamogeton fruits in most of the samples suggests the stable existence of a pondweed population in the western part of the lake.

\section{KW20/4}

Few pollen grains of Cladium were noted in the lower and middle parts of the core, but their seeds were not found. Today, fen-sedge does not exist in the southern part of the lake. Singular grains could come from long-distance transportation or from temporarily developed small plant communities. The flora of high reed bed was represented by pollen and seeds of T. latifolia, probably $T$. angustifolia (Sparganium emersum type, Typha sp.) and Schoenoplectus. Low reed bed included Carex (pollen and seeds), ferns (spores) and seeds of $J$. bulbosus, $R$. sceleratus and P. amphibium.

Neither pollen nor seeds of $L$. dortmanna were found in this core. According to the information provided by the manager of BTNP, Mr. Wojciech Błoniarz, during the last few years, few specimens of flowering Lobelia were observed in this place, which prompted us to select this site for coring. However, this fact was not confirmed during the field observation conducted in July 2020.

Pollen of $M$. alterniflorum occurred abundantly in the sediments above $6 \mathrm{~cm}$, and fruits were also found in the samples taken at depths of 2 and $4 \mathrm{~cm}$ (up to 6 specimens). Pollen grains of numerous other aquatic macrophytes were present in this core: $R$. aquaticus $(30-10 \mathrm{~cm})$, Utricularia (4 cm), Alisma 

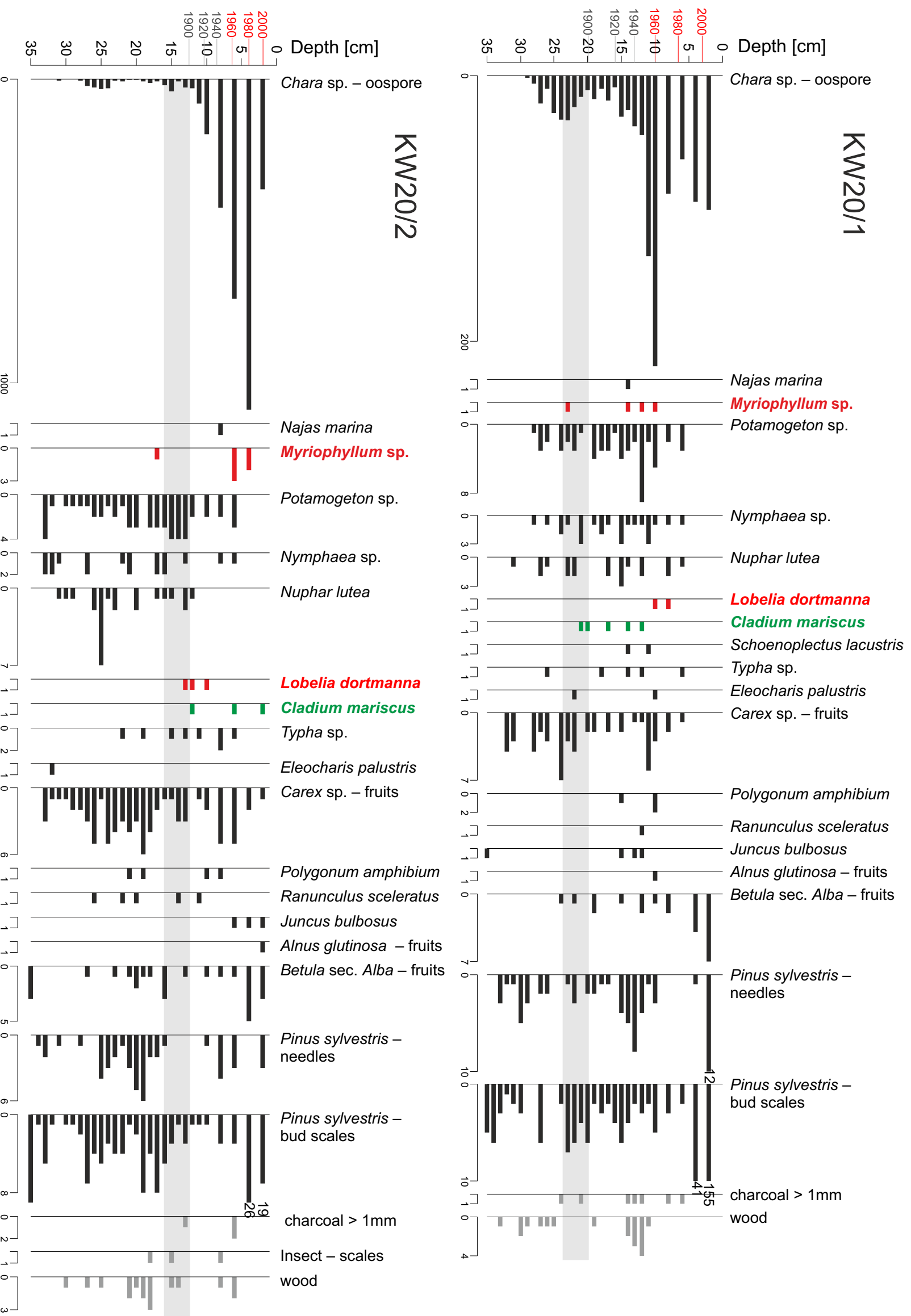

Fig. 6A. Macrofossil diagrams of cores KW20/1-KW20/2. Red dates $-{ }^{210} \mathrm{~Pb}$-based age dates derived from the model, gray dates - linear approximation of the model assuming constant accumulation rate. Scales represent numbers in sample volume. Out of scale values are given next to the bars. Gray bar indicates approximate age of water level drop 


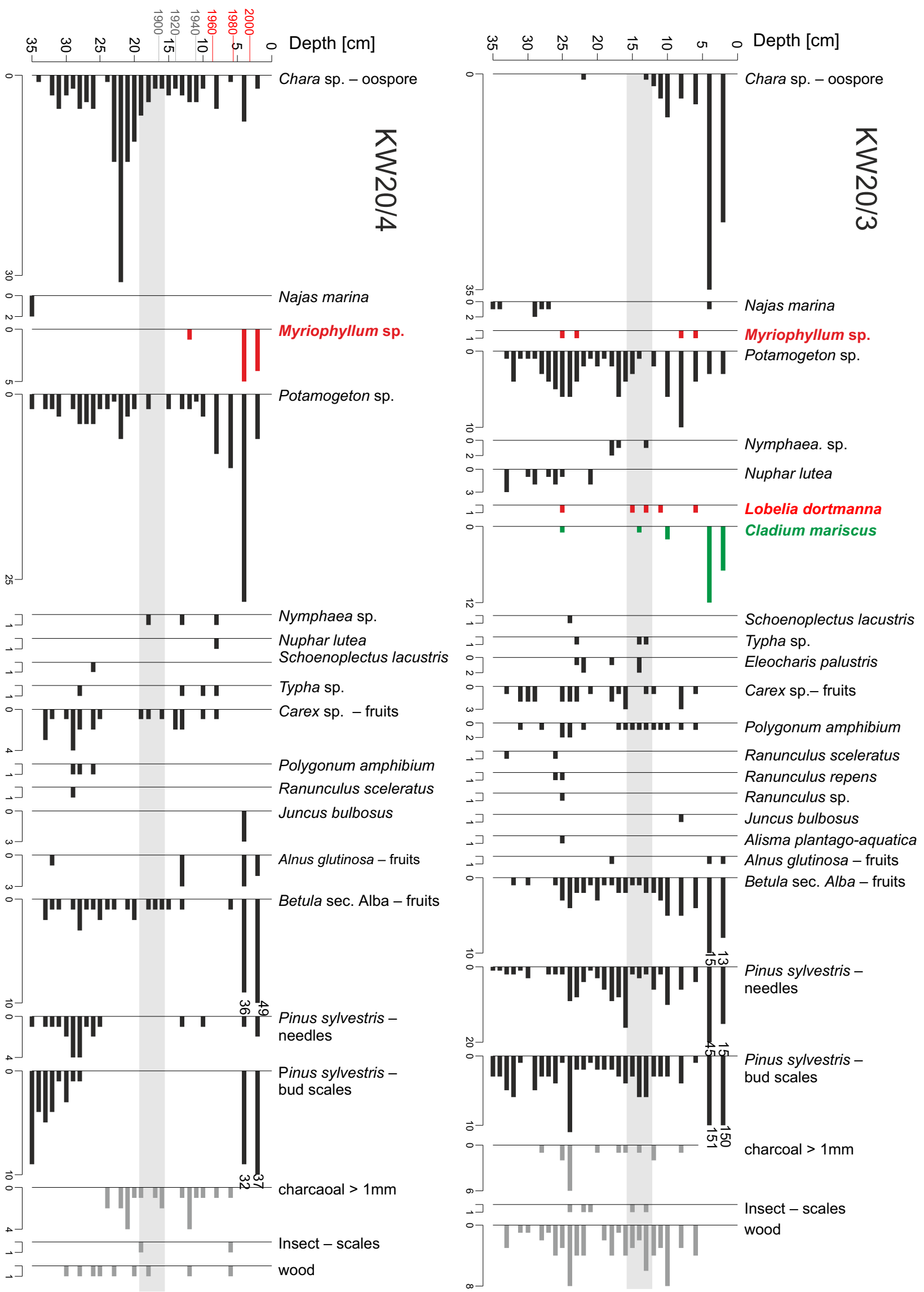

Fig. 6B. Macrofossil diagrams of cores KW20/3-KW20/4. Red dates $-{ }^{210} \mathrm{~Pb}$-based age dates derived from the model, gray dates - linear approximation of the model assuming constant accumulation rate. Scales represent numbers in sample volume. Out of scale values are given next to the bars. Gray bar indicates approximate age of water level drop 
plantago-aquatica $(4 \mathrm{~cm})$, and Myriophyllum spicatum $(2 \mathrm{~cm})$. Fruits of $N$. marina $(35 \mathrm{~cm})$, Nymphaea $(8-18 \mathrm{~cm})$, and Nuphar lutea $(8 \mathrm{~cm})$ were found during macrofossil analysis. Potamogeton fossils were the most abundant (up to 28 fruits).

\section{DISCUSSION}

\section{EVIDENCE AND TIMING OF LOBELIA AND} CLADIUM CO-OCCURRENCE IN THE LAKE

The investigations revealed a low representation of both pollen and seeds of $L$. dortmanna. The results are in agreement with the conclusions of earlier studies (Moeller, 1978; Milecka and Obremska, 2002; Milecka, 2005). Lobelia is an aquatic plant, but the flowering shoot grows above the water surface and is pollinated by insects. Dąmbska (1965) and Moeller (1978) found that the deeper the depth of water is, the smaller the number of flowering plants will be. Plants growing below 1.7-2 m do not flower at all. It has also been proved that some specimens do not open their flowers and undergo self-pollination (Faegri and Van der Pijl, 1979). Spence (1982) reported that the process of seed production requires a large amount of light. The significance of adequate light conditions was also stressed by Szmeja and Bociąg (2004), Banaś et al. (2012) and Ronowski et al. (2020). Consequently, low frequency of microand macrofossils is observed in lacustrine sediments rich in organic matter. This observation was confirmed in the present study. Although two cores (KW20/1 and KW20/2) were collected from the direct neighborhood of flowering Lobelia patches, the frequency of occurrence of micro- and macrofossils was low. This proves that this species occurs along with other macrophytic plants in the lake. The lack of Lobelia pollen in the long sections of cores, confirmed by the lack of fruits, suggest that Lobelia was absent in the studied periods. The complete lack of Lobelia fossils in the older parts of four cores of sediments rich in organic matter and also in the long deep-water core (Milecka and Tobolski, 2015, and this research) suggests that Lobelia is a very recent component of aquatic vegetation in Lake Krzywce Wielkie. It likely appeared by the end of the 19th century.

Studies that aimed to determine the presence of Lobelia in the temperate climate zone based on pollen analysis of organic sediments were previously carried out in Europe. According to Hjelmroos-Ericsson (1981) and Milecka (2005), L. dortmanna developed in Tuchola Forest lakes in the late Holocene period, at $\sim 3800$ yrs BP in Gacno Wielkie and at 2000 yrs BP in Nierybno, Lake Linowskie and Moczadło. On Wolin Island (NW Poland), Lobelia was found since 1700 yrs BP (Latałowa, 1992). Odgaard (1994) identified Lobelia pollen occurring from $\sim 4000$ yrs BP in northern West Jutland. In Lake Krzywce Wielkie, Lobelia was documented only in the youngest sediments and it constitutes very recent floral species of this lake. The spread of Lobelia to the temperate zone of Central Europe during the late Holocene (decline of interglacial cooling) can be explained by its climatic demands and ecological optimum related to the cold climate of the boreal zone (Odgaard, 1994; Birks, 2000). The middle Holocene climatic optimum did not favor the existence of this boreal species. According to Farmer (1989), the temperature of $17^{\circ} \mathrm{C}$ in the month of July is a limiting factor for its expansion. Therefore, the occurrence of Lobelia was documented in many works mainly during the late Holocene cooling. However, it is not the case of Krzywce Wielkie, where Lobelia presence was documented during warming after the Little Ice Age (20th and 21st centuries). Thus, it is likely that environmental conditions (e.g., land use) and human activity as well significantly influence the development of Lobelia populations.

The pollen profile of Krzywce Wielkie demonstrated the consistent presence of $C$. mariscus from the beginning of the Holocene period (core KW/2014; Milecka and Tobolski, 2015) and in all cores of the littoral zone. However, relatively high content of fruits was found only in core KW20/3.

\section{DISTRIBUTION AND CONSERVATION IN POLAND AND EUROPE}

The existence of both species in BTNP is considered to be of environmental value because it is within the geographical limits of Poland and hence is under strict jurisdiction (Regulation of the Ministry of Environment of 9 October 2014). Lobelia reaches the southern border of occurrence in Poland (Sculthorpe, 1985; Szmeja, 2014a). However, there are some sites in western Europe that are situated farther south (e.g., in France). Many authors (Czubiński, 1950; Kucharczyk, 2000; Herbichowa and Wołejko, 2004) assumed that the eastern European 
border of the range of C. mariscus is in Poland. Considering the fact that the species is found in scattered locations south and east of the study area, for example, in Latvia (Salmina, 2004) and Czechia (Pokorny et al., 2010), it would be better to assume that it shows a "scattered distribution" and avoid the determination of an accurate border. As these species predominantly occur within the borders of their occurrence in Poland, their IUCN status in Poland differs from their global and European status. According to Maiz-Tome (2016), L. dortmanna globally (or in Europe) is not likely to meet the threshold for being included in the "Vulnerable" IUCN category and is assessed as "Least Concern." But locally, in Poland, the status of this species was changed from vulnerable (Zarzycki and Szeląg, 2006) to endangered (Kaźmierczakowa et al., 2016). Similar status has been given to C. mariscus in Europe and the world (Lansdown et al., 2017), but in Poland it is placed under the category "Near Threatened" (Kaźmierczakowa et al., 2016).

The reasons for the disappearance of Lobelia sites were widely discussed, and considered to be related to eutrophication and changes in land use over time (Farmer, 1989; Szmeja, 1997, 1998; Kraska et al., 2013). The causes for the disappearance of Cladium sites can be attributed to both natural (vegetation succession) and anthropogenic changes of habitats, such as changes in water level and trophy (Herbichowa and Wołejko, 2004; Karcz, 2008). Report under Article 17 of the Habitats Directive Period 2007-2012 indicated the factors that pose a threat to their existing habitat, which include physical and chemical changes in water bodies (29\%), vegetation succession/ biocenotic evolution (16\%) and other changes related to human activities (55\%). Despite many known threats, new modern localities of both Lobelia (Chmara, 2007; Chmara et al., 2015b) and Cladium (Namura-Ochalska, 2004; Gałka, 2007; Karcz, 2008; Towpasz and Stachurska-Swakoń, 2009; Krajewski, 2011) are still being identified in Poland.

\section{DIFFERENCES IN CONTEMPORARY ECOLOGICAL REQUIREMENTS OF LOBELIA AND CLADIUM}

Lobelia dortmanna and Cladium mariscus differ in their spatial ranges. Contrary to the boreal range of Lobelia, C. mariscus is an evergreen reed bed plant widely spread across all the continents except Antarctica (Pawłowska, 1972) and is considered to be an indicator of temperate warm climate (Tobolski, 2006; Brande, 2008). Both species are found in the areas subjected to a strong oceanic influence (Czubiński, 1950; Szmeja, 2014a). In Poland, Cladium tend to spread toward the north (Kłosowski, 1986-87) and separate sites are found in calcareous mires of eastern Poland (Fijałkowski, 1959; Buczek, 2005), whereas the present occurrence of Lobelia species is limited to northwestern Poland.

Both species differ in their ecological demands. Podbielkowski and Tomaszewicz (1994) reported that Cladium is an expansive plant inhabiting eutrophic or dystrophic lakes. On the contrary, Zarzycki et al. (2002) classified it as a species of oligotrophic habitat. Ellenberg et al. (1991) present medium requirements with regard to nitrogen content. Cladium species represent group 3 ("indicator of more or less infertile sites"), while Lobelia is included in group 1 ("indicator of extremely infertile sites"). The biggest difference in their demands relates, however, to $\mathrm{pH}$. According to Ellenberg et al. (1991), C. mariscus is an indicator of basic conditions prevalent in calcareous or other high-pH soils where the maximum $\mathrm{pH}$ is found to be 9 . In contrast, Lobelia is an indicator of acidic conditions, where $\mathrm{pH}$ decreases to 2 , and it exceptionally occurs in sediments with nearly neutral $\mathrm{pH}$. Herbichowa and Wołłejko (2004) and Mróz (2010) regarded C. mariscus as a calciphilous plant. Rothmaler (1994) reported that it can grow on basic and lime-rich substrates. However, it is also known that saw-sedge is capable of growing on habitats poor in calcium carbonate (Grosse-Brauckmann, 1964; Marek, 1991; Sawilska and Dąbrowska, 1995; Brande, 2008; Tobolski and Gałka, 2008). According to Gałka (2007), appropriate climatic conditions, especially temperature and air moisture, are the main factors that contribute to the development of a Cladium population instead of the abundance of calcium carbonate. Calcium plays a key role only at the sites located adjacent to the border of the range of the population. In these regions, calcium compensates for the heat shortage due to the exothermic reaction of calcium oxide and water. This means that the calcareous soil is important, but only in the case of the eastern and northern sites of the range. The lack of the necessity of calciphilous 
Table 3. Ranges of calcium content, acidity and conductivity of water documented in Lobelian lakes and other lakes in BTNP

\begin{tabular}{|c|c|c|c|}
\hline Locality and references & $\begin{array}{c}\mathrm{Ca} \\
\mathrm{mg} / \mathrm{l}\end{array}$ & $\mathrm{pH}$ & conductivity \\
\hline $\begin{array}{l}7 \text { Lobelian lakes in Pomerania, NW Poland, some of them are degraded } \\
\text { (Kraska and Piotrowicz, 1994) }\end{array}$ & $1.45-23.6$ & $4.6-8.77$ & $42-170$ \\
\hline 16 lakes with Isoëto-Lobelietum community from Pomerania (Kłosowski, 1994) & $6-17.6$ & $6.4-8$ & - \\
\hline $\begin{array}{l}18 \text { lakes with Myriophylletum alterniflori community from Łęczyńsko-Włodawskie } \\
\text { Lakeland, E Poland (Kłosowski, 1994) }\end{array}$ & $8.2-17.6$ & $6.5-7.6$ & - \\
\hline $\begin{array}{l}9 \text { Lobelian lakes in Zaborski Landscape Park, Tuchola Forest (including lakes in } \\
\text { BTNP) (Gonet et al., 1994) }\end{array}$ & $4-13$ & $4.2-6.9$ & $38-81$ \\
\hline Lakes of Krzywce-Błotko channel (Zdanowski, 2004) & $6.4-10.4$ & $6.9-7.7$ & $39.8-69.3$ \\
\hline Lakes of Struga Siedmiu Jezior (Zdanowski, 2004) & $43.3-48.9$ & $8-8.5$ & $215-232$ \\
\hline
\end{tabular}

sediments was also reported by Pokorny et al. (2010) in relation to fens.

Lobelia occurs in acidic to neutral water, that is, pH 4-7 (Zarzycki et al., 2002). Hannon and Gaillard (1997) reported its presence in waters with $\mathrm{pH}$ 5.0-6.7. There is a wide range of calcium content in Lobelian lakes and the lakes with Cladium (Table 3). The lakes of the Krzywce-Błotko canal (including Krzywce Wielkie) have Ca contents similar to that of Lobelian lakes, while the concentration of $\mathrm{Ca}$ is found to be much higher in other lakes with Cladium in BTNP (Fig. 1). Thus, from this point of view, the presence of Cladium in Lake Krzywce Wielkie is exceptional. On the other hand, it presents a wide ecological scale in terms of $\mathrm{pH}$ because Cladium occurs in both the calcium-rich Struga Siedmiu Jezior stream and the calcium-poor Krzywce-Błotko canal.

\section{LAND-USE, HYDROLOGICAL AND TROPHY CHANGES}

Presently, Krzywce Wielkie is considered to be an endorheic lake. However, a topographic map from $1874 \mathrm{AD}$ shows a drainage canal connecting it with Lake Krzywce Małe. On the younger maps, the drainage canal is clearly marked, which indicates that it existed at least before $1900 \mathrm{AD}$. According to Mr. Błoniarz, manager of BTNP, this drainage canal has been dry for many years. The altitude of the drainage threshold is about $124.4 \mathrm{~m}$ a.s.l., and the water level of the lake as shown on topographic maps (1965, 1992, 1:10,000, see Nienartowicz 2012) is $123.5 \mathrm{~m}$ a.s.l. In the years 2000-2004, the water level was found to be $123.44 \mathrm{~m}$ a.s.l., which slightly increased in the following years; however, it has not exceeded $123.8 \mathrm{~m}$ a.s.l. (Marszelewski et al., 2016). When the threshold was dug in the 19th century, the water level was the same as or higher than the altitude of the threshold (124.4 $\mathrm{m}$ a.s.l). Thus, the outflow through the drainage canal caused a decrease in the water level of the lake by at least $60-90 \mathrm{~cm}$, and strongly influenced the littoral zone of the lake and the plant communities living therein. The above is reflected in macrofossil diagrams, and the gray bar roughly separate the two periods of higher and lower lake water levels (Figs 6A, B and 7).

Exposure of the littoral areas of the lake as a consequence of the decreasing water level created conditions favorable for the development of Lobelia populations. Most of their fruits were found in sediments deposited at the time of the digging of the drainage canal or later. Pollen of Lobelia in core KW20/1 appeared likely at the time of drainage construction, and in core KW20/2 a singular grain was found shortly before the decrease of the water level. One seed of Lobelia in core KW20/3 at the depth of $22 \mathrm{~cm}$ was found probably due to disturbing the sediments in the course of the drilling (reposition from the upper layers by the corer). Hence, a Lobelia succession at the end of the 19th century would be possibly supported by the decrease of the water level. New habitats in shallow waters enabled the potential development of new-coming species.

The analyses of old maps provide additional supporting evidence explaining the development of conditions favorable for Lobelia. At the turn of the 18th and 19th centuries, Schröter's map showed open spaces on the eastern and western sides of the lake (Nienartowicz, 2012). They were suitable for rye cultivation or pastures. Riemann's map, prepared in $1860 \mathrm{AD}$, showed a similar distribution. There was no drainage canal during that time, but fields existed in the west and southeast of the lake. Thus, only the areas adjacent to the northeastern part of the lake (cores KW20/1 and KW20/2) were covered by forests. The presence of cultivated fields or pastures undoubtedly influenced 

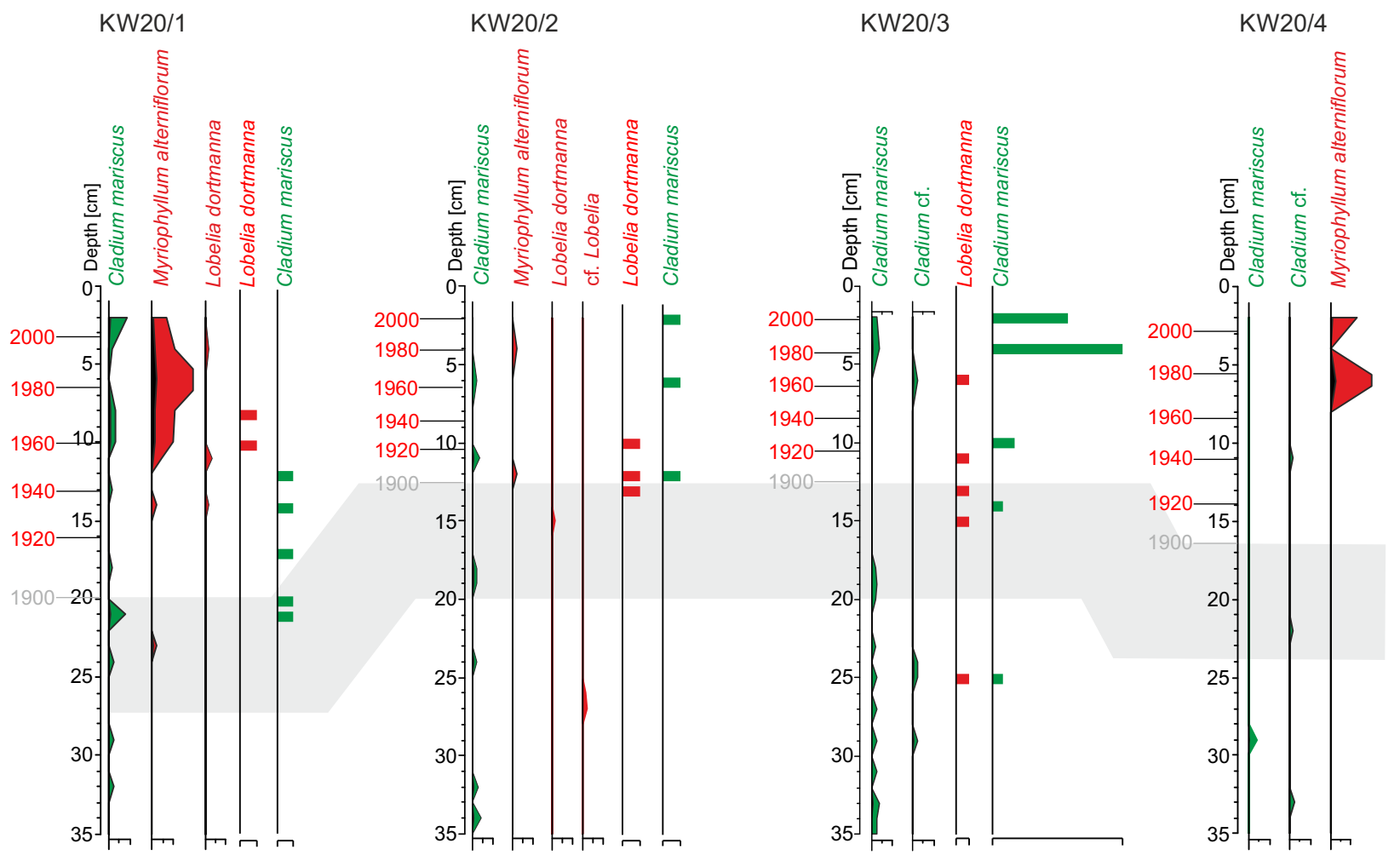

Fig. 7. Summary diagram of the content of pollen and macrofossils of the indicative species discussed in the article. For explanations of scale, dates and gray bar see Figs 4-6

the trophy of the lake by the surface discharge of nutrients. The occurrence of Rumex and $P$. lanceolata and only a few pollen grains of weeds indicates that the neighborhood areas around the lake shore were used as pastures rather than as cultivation sites in the 19th century. Agricultural activity was abandoned and forest communities developed at the end of the 19th century, which is confirmed by the presence of a unit of Prussian Forestry Academy in $1894 \mathrm{AD}$. According to the map created in $1920 \mathrm{AD}$, the whole area of presently existing BTNP is covered by forests (Nienartowicz, 2012). The development of forests restricted the supply of nutrients and resulted in a decrease of the trophy of the lake. Additionally, pine forests and boggy patches protected the lake and contributed to decreasing $\mathrm{pH}$ and oligotrophy (Kraska et al., 1998; Zdanowski, 2004).

The decrease of trophy at the turn of the 19th and 20th centuries is manifested by an increase in the Lobelia population, as well as by the growth of $M$. alterniflorum, J. bulbosus and Chara sp. Three species of Myriophyllum are found in Europe, and all of them are present in BTNP (Wróbel and Hutorowicz, 2012). Among them, $M$. alterniflorum adapted to the low nutrient content and constitutes the typical component and indicator of oligotrophic lakes (Rutkowski, 2004). According to Zarzycki et al. (2002), trophy of $M$. alterniflorum is classified as level 2-3 (oligotrophy to mesotrophy), while the other species are classified as level 4 (eutrophy). Juncus bulbosus grows in oligotrophic habitats (Zarzycki et al., 2002) and appeared not earlier than the second half of the 20th century. Chara oospores were not identified to species level; however, species of Characeae exist in the clear waters of oligotrophic or mesotrophic lakes (Pełechaty et al., 2007; Schubert et al., 2018), and may be associated with rare plants such as $L$. dortmanna, L. uniflora and Isoëtes (Bertrin et al., 2013). The decrease of trophy during the 20th century is also indicated by the lower content of macrofossils of eutrophic species, such as P. amphibium, R. sceleratus, Nuphar and Nymphaea, in the younger parts of all the cores. A decreasing trend was observed with regard to the contamination and concentration of $\mathrm{P}, \mathrm{K}$ and $\mathrm{Ca}$ in the selected lakes of BTNP (Wielkie Gacno, Zmarłe, Czarne i Ostrowite), as reported by Chmara (2006). This trend is favorable for the Lobelian lakes situated within the Park, and is considered to be the result of land-use changes and the establishment of BTNP.

The near-surface layers of sediments were characterized by a lower diversity of herbs due 
to the unification of the vegetation cover and the development of a pine forest around Lake Krzywce Wielkie. However, in cores KW20/1, KW20/2 and KW20/4 the increased presence of indicators related to human activities was noted (Fig. 5A, B), mainly Rumex and Secale, which are wind-pollinated plants and release large amounts of pollen (Meese and Morris, 1984; Subba-Reddi and Reddi, 1986; Sugita et al., 1999). Their presence in the upper part of the sediments in the study area is the result of the regional transport. Thus, the increased occurrence of Rumex and Secale is the consequence of a huge production of pollen and the common presence of these species in the 20th century under the strong human activity.

\section{CONCLUSION}

Paleobotanical analysis of the sediments revealed that a $C$. mariscus population developed during the early Holocene and has almost continuously existed in Lake Krzywce Wielkie since then. While $L$. dortmanna is a new species that appeared in this lake at the end of the 19 th century.

In the younger part of the cores, higher frequencies of oligotrophic species, other than $L$. dortmanna, such as M. alterniflorum, J. bulbosus and Charophytes, were noted. There was a concurrent decrease in the population of aquatic macrophytes typical for eutrophic water, namely $P$. amphibium, $R$. sceleratus, Nuphar and Nymphaea. The spread of L. dortmanna and other oligotrophic species was possible due to the artificial lowering of the lake water level and the changes in the land use of adjacent areas, which mainly included the abandonment of agricultural activities, grazing and the development of a pine forest. The drainage canal dug by the end of the 19th century resulted in a decrease of water level, which caused changes in the littoral zone of the lake and enabled the rebuilding of the plant communities and the development of new species. The changes in the surroundings of the lake favored the filtering of water from the catchment areas and resulted in the smaller supply of nutrients, which enabled the development of oligotrophic species communities. The establishment of BTNP at the end of the 20th century contributed to the complex protection and conservation of the catchment area, which further limited the potential eutrophication of habitats.

The recent development of $L$. dortmanna population proves that the presence of this oligotrophic species is generally possible under the present environmental conditions in the temperate zone, despite a continuous supply of nutrients to the lakes in the industrial countries as a result of agricultural activities and synanthropic changes of flora and vegetation. The necessary conditions are related to the catchment. Forest cover, especially pine forest, is an important factor because of the low $\mathrm{pH}$ of the soil and infertile habitat. It is essential for such lakes that the adjacent areas would be protected by law so that changing the landuse would be impossible.

Potentially, a gradual and slow decline of Cladium could be expected due to the oligotrophication of the water of a lake. However, the often contradictorily defined ecological demands of Cladium and its presence in various habitats prevent us from drawing such a conclusion. Perhaps, its ability to adapt to different habitats contributes to its persistence in Lake Krzywce Wielkie for a longer period of time.

\section{ACKNOWLEDGEMENTS}

The research was carried out with the financial support of State Forest and the cooperation of National Park "Tuchola Forest”. We thank Magdalena Kochanowska for capable administration and Wojciech Błoniarz for his essential help during the field work. M. Suchorska, R. Jagodziński, K. Leszczyńska and K. Pleskot kindly helped in laboratory works.

\section{REFERENCES}

Appleby, P.G., Oldfield, F., 1978. The calculation of lead-210 dates assuming a constant rate of supply of unsupported ${ }^{210} \mathrm{~Pb}$ to the sediment. Catena $5,1-8$. https://doi.org/10.1016/S0341-8162(78)80002-2

Bajkiewicz-Grabowska, E., 2004. Podatność jezior na eutrofizację. In: Ekosystemy wodne Parku Narodowego „Bory Tucholskie”. IRS, Olsztyn, pp. 17-32.

Banaś, K., Gos, K., Szmeja, J., 2012. Factors controlling vegetation structure in peatland lakes - Two conceptual models of plant zonation. Aquatic Botany 96, 42-47. https://doi.org/10.1016/j. aquabot.2011.09.010

Berglund, B.E., Ralska-Jasiewiczowa, M., 1986. Pollen analysis. In: Berglund, B.E. (ed.) Handbook of Holocene Palaeoecology and Palaeohydrology, pp. 455-483. 
Bertrin, V., Boutry, S., Dutartre, A., Lambert, E., 2013. Characeae communities in the Medoc area lakes (South-West France). Elements of ecology and distribution. Acta Botanica Gallica 160, 131-140.

Beug, H.J., 2004. Leitfaden der Pollenbestimmung. Gustav Fischer Verlag, Stuttgart, pp. 30-42.

Birks, H.H., 2000. Aquatic macrophyte vegetation development in Krakenes Lake, western Norway, during the Late-Glacial and early-Holocene. Journal of Paleolimnology 23: 7-19.

Błoniarz, W., Choiński, A., Ptak, M., 2016. Batymetria jezior PN „Bory Tucholskie“. In: Choiński, A., Kochanowska, M., Marszelewski, W. (eds) Przyroda abiotyczna Parku Narodowego „Bory Tucholskie”. Park Narodowy „Bory Tucholskie”, Charzykowy, pp. 243-262.

Bociąg, K., 2011. Ocena stanu, projekt monitoringu i działań ochronnych siedlisk przyrodniczych wód śródlądowych Parku Narodowego „Bory Tucholskie”. Gdańsk.

Brande, A., 2008. Holocene Paleoecology of Cladium mariscus (L.) Pohl in the Spree-Havel region of Berlin and Brandenburg (Germany). Studia Limnologica et Telmatologica 2, 43-46.

Bruel, R., Sabatier, P., 2020. serac: an R package for ShortlivED Radionuclide chronology of recent sediment cores. Journal of Environmental Radioactivity 225,106449 .

Brzozowski, M., Kowalewski, G., Szczuciński, W., Kaczmarek, L., Pełechaty, M., 2021. Preliminary evidence of an endangered species benefiting from moderate climate warming: A paleolimnological study of the charophyte Lychnothamnus barbatus. Aquatic Conservation: Marine and Freshwater Ecosystems 31, 2673-2689. https://doi.org/10.1002/ aqc.3672

Buczek, A., 2005. Siedliskowe uwarunkowania, ekologia, zasoby i ochrona kłoci wiechowatej Cladium mariscus L. Pohl. w Makroregionie Lubelskim. Acta Agrophysica PAN 129, 9.

Chmara, R., 2006. Wieloletnie zmiany odczynu, stężenia fosforanów i wapnia w wodzie jezior: Ostrowite, Wielkie Gacno, Zmarłe i Czarne. In: Banaszak, J., Tobolski, K. (eds) Park Narodowy Bory Tucholskie u progu nowej dekady. Wydawnictwo UKW, Bydgoszcz, pp. 49-56.

Chmara, R., 2007. New sites of lobelia lakes in Poland. Badania Fizjograficzne nad Polską Zachodnią B 56, 173-180.

Chmara, R., Szmeja, J., Banaś, K., 2014. Factors controlling the frequency and biomass of submerged vegetation in outwash lakes supplied with surface water or groundwater. Boreal Environment Research 19 168-180.

Chmara, R., Banaś, K., Szmeja, J., 2015a. Changes in the structural and functional diversity of macrophytes communities along an acidity gradient in softwater lakes. Flora 216, 57-64. https://doi. org/10.1016/j.flora.2015.09.002
Chmara, R., Dominik, J., Braun, M., Piątek, G., 2015b. New sites of Lobelia dortmanna (Campanulaceae) in Poland. Fragmenta Floristica and Geobotanica 22, 97-100.

Czubiński, Z., 1950. Zagadnienia geobotaniczne Pomorza. Badania Fizjograficzne nad Polską Zachodnią 2, 439-658.

Davidson, T.A., Reid, M.A., Sayer, C.D., Chilcott, S., 2013. Palaeolimnological records of shallow lake biodiversity change: exploring the merits of single versus multi-proxy approaches. Journal of Paleolimnology 49, 431-446. https://doi.org/10.1007/s10933013-9696-8

Dąbska, I., 1965. Roślinność litoralu jezior lobeliowych Pojezierza Kartuskiego. Prace Komisji Biologicznej PTPN 30, 1-51.

Dysarz, R., 1998. Zarys geomorfologii i typy krajobrazu naturalnego w północnej części Borów Tucholskich. In: Banaszak, J., Tobolski, K. (eds) National Park „Bory Tucholskie”. Stan poznania przyrody na tle kompleksu leśnego Bory Tucholskie. Akademia Bydgoska, Bydgoszcz, pp. 9-18.

Dziuba, M.K., Herdegen-Radwan, M., Pluta, E., Wejnerowski, Ł., Szczuciński, W., Cerbin, S., 2020.Temperature increase altered Daphnia community structure in artificially heated lakes: a potential scenario for a warmer future. Scientific Reports 10, 13956. https://doi.org/10.1038/s41598-020-70294-6

Ellenberg, H., Weber, H.E., Düll, R., Wirth, V., Werner, W., Paulissen, D., 1991. Zeigerwerte von Pflanzen in Mitteleuropa. Scripta Geobotanica 18, $1-248$

Farmer, A.M., 1989. Lobelia dortmanna. Biological Flora of the British Isles. Journal of Ecology 77, 1161-1173.

Faegri, K., van der Pijl, L., 1979. The Principles of Pollination Ecology. Pergamon Press, Oxford.

Fijałkowski, D., 1959. Kłoć wiechowata Cladium mariscus (L.) Pohl. w województwie lubelskim. Annales UMCS Sect. C 14, 343-357.

Filbrandt-Czaja, A., 2009. Studia nad historią szaty roślinnej i krajobrazu Borów Tucholskich. Wydawnictwo Naukowe UMK, Toruń, pp. 1-131.

Foster, I.D.L., Mighall, T.M., Proffitt, H., Walling, D.E., Owens, P.N., 2006. Post-depositional ${ }^{137} \mathrm{Cs}$ mobility in the sediments of three shallow coastallagoons, SW England. Journal of Paleolimnology 35, 881895. https://doi.org/10.1007/s10933-005-6187-6

Gałka, M., 2007. Zmiany jeziorno-torfowiskowe w ujściowym odcinku Strugi Siedmiu Jezior. Prace Zakładu Biogeografii i Paleoekologii UAM In Poznań 8, Bogucki Wydawnictwo Naukowe, Poznań.

Gałka, M., Tobolski, K., 2006. Materiały do rozmieszczenia subfosylnych i współczesnych stanowisk kłoci wiechowatej Cladium mariscus (L.) w Parku Narodowym „Bory Tucholskie” In: Banaszak, J., Tobolski, K. (eds) Park Narodowy „Bory Tucholskie" u progu nowej dekady, Wyd. Uniwersytetu im. Kazimierza Wielkiego, pp. 71-86. 
Gonet, S.S., Śpiewakowski, E.R., Dziamski, A., 1994. Skład chemiczny wód i właściwości osadów dennych jezior lobeliowych Zaborskiego Parku Krajobrazowego. In: Kraska, M. (ed.) Jeziora lobeliowe. Charakterystyka, funkcjonowanie i ochrona. Idee ekologiczne, 6, Sorus, Poznań, pp. 149-157.

Goslar, T., Czernik, J., Goslar, E., 2004. Low-energy ${ }^{14} \mathrm{C}$ AMS in Poznań Radiocarbon Laboratory, Poland. Nuclear Instruments and Methods in Physics Research B 223-224, 5-11. https://doi. org/10.1016/j.nimb.2004.04.005

Goslar, T., van der Knaap, W.O., Kamenik, Ch., van Leeuwen, J.F.N., 2009. Free-shape ${ }^{14} \mathrm{C}$ age-depth modelling of an intensively dated modern peat profile. Journal of Quaternary Science 24, 481-499. https://doi.org/10.1002/jqs.1283

Gostyńska-Jakuszewska, M., Lekavičius, A., 1994. Selected boreal and subboreal species of vascular plants in the flora of Poland and Lithuania. Part II. Fragmenta Floristica et Geobotanica 39 (1), 255-276.

Grimm, E.C., 1992. Tilia and Tilia-Graph. Pollen Spreadsheet and Graphics Programs. In: 8th International Palynological Congress (President: A. Pons) Aix-en-Provence, September 6-12. Program and Abstracts, 56.

Grosse-Brauckmann, G., 1964. Einige wenig beschtete Pflanzenreste in nordwestdeutschen Torfen und die Art Ihres Vorkommens. Geologisches Jahrbuch 81, Hannover, pp. 621-643.

Hannon, G.E., Gaillard, M.J., 1997. The plant macrofossil record of past lake-level changes. Journal of Paleolimnology 18, 15-28.

Heegaard, E., Birks, H.H., Gibson, C.E., Smith, S.J., Wolfe-Murphy, S., 2001. Species-environmental relationship of aquatic macrophytes in Northern Ireland. Aquatic Botany 70, 175-223. https://doi. org/10.1016/S0304-3770(01)00161-9

Herbichowa, M., Wołejko, L., 2004. Torfowiska nakredowe (Cladietum marisci, Caricetum buxbaumi, Schoenetum nigricantis). In: Herbich, J. (ed.) Wody słodkie i torfowiska. Poradniki ochrony siedlisk i gatunków Natura 2000 - podręcznik metodyczny. Ministerstwo Środowiska, Warszawa. T. 2, pp. 163-172.

Hjelmroos-Ericsson, M., 1981. Holocene development of Lake Wielkie Gacno area, northwestern Poland. Thesis 10, University of Lund, pp. 1-101.

Juggins, S., 2020. rioja: Analysis of Quaternary Science Data. $R$ package version 0.9-26, https://cran.rproject.org/package=rioja.

Karcz, G., 2008. O stanowiskach kłoci wiechowatej Cladium mariscus (L.) w Pszczewskim Parku Krajobrazowym. Biuletyn Parków Krajobrazowych Wielkopolski 13(15), 121-129.

Kaźmierczakowa, R., Bloch-Orłowska, J., Celka, Z., Cwener, A., Dajdok, Z., Michalska-Hejduk, Z., Pawlikowski, P., Szczęśniak E., Ziarnek, K., 2016. Polish red list of pteridophytes and flowering plants. Kraków: Instytut Ochrony Przyrody Polskiej Akademii Nauk.
Kłosowski, S., 1986-87. Cladietum marisci (All. 1922) Zobrist 1935 w północno-wschodniej Polsce na tle warunków siedliskowych. Fragmenta Floristica et Geobotanica 31-32(1-2), 207-223.

Kłosowski, S., 1994. Ekologia głównych zbiorowisk roślin wodnych z klasy Littorelletea uniflorae Br.-Bl. Et Tx. 1943 w Polsce. In: Kraska, M. (ed.) Jeziora lobeliowe. Charakterystyka, funkcjonowanie i ochrona. Sorus, Poznań, pp. 93-104.

Kochanowska, M., Kochanowski, J., Tobolski, K., 2013. Preliminary information on spreading of Cladium mariscus and Lobelia dortmanna in the littoral of the Lake Krzywce Wielkie (National Park „Bory Tucholskie”). Studia Limnologica et Telmatologica, 7(1), 13-19.

Kochanowski, J., Tobolski, K., 2010. A new locality of lobelia (Lobelia dortmanna L.) in Lake Krzywce Wielkie ("Bory Tucholskie" National Park). Studia Limnologica et Telmatologica 4(2), 61-64.

Kornijów, R., Kowalewski, G., Sugier, P., Kaczorowska, A., Gąsiorowski, M., Woszczyk, M., 2016. Towards a more precisely defined macrophytedominated regime: the recent history of a shallow lake in Eastern Poland. Hydrobiologia 772, 45-62. https://doi.org/10.1007/s10750-015-2624-3

Kowalewski, G., 2002. Granice Borów Tucholskich. In: Banaszak, J., Tobolski, K. (eds) Park Narodowy „Bory Tucholskie” na tle projektowanego rezerwatu biosfery. Homini, Charzykowy, pp. 121-138.

Kowalewski, G.A., Kornijów, R., McGowan, S., Woszczyk, M., Suchora, M., Bałaga, K., Kaczorowska, A., Gąsiorowski, M., Szeroczyńska, K., Wasiłowska, A., 2013. Persistence of protected, vulnerable macrophyte species in a small, shallow eutrophic lake (eastern Poland) over the past two centuries: implications for lake management and conservation. Aquatic Botany 106, 1-13.

Krajewski, Ł., 2011. Zespół Cladietum marisci w piaskowni w Dąbrowie Górniczej na tle rozmieszczenia kłoci wiechowatej Cladium mariscus w Polsce. Chrońmy Przyrodę Ojczystą 67(3), 276-283.

Kraska, M., Piotrowicz, R., 1994. Roślinność wybranych jezior lobeliowych na tle warunków fizyczno-chemicznych ich wód. In: Kraska, M. (ed.) Jeziora lobeliowe. Charakterystyka, funkcjonowanie i ochrona. Idee ekologiczne 6, Sorus, Poznań, pp. 67-83.

Kraska, M., Dąbrowska, B.B., Pełechaty, M., 1998. Vegetation and concentration of humus compounds in selected lobelian lakes ecotones. In: Radwan, S. (ed.) Fresh water ecotones. UMCS Lublin, pp. 89-98.

Kraska, M., Klimaszyk, P., Piotrowicz, R., 2013. Anthropogenic changes in properties of the water and spatial structure of the vegetation of the lobelia lake Modre in the Bytów Lakeland. Oceanological and Hydrobiological Studies 42(3), 302-313. https://doi.org/10.2478/s13545-013-0087-6

Królikowska, J., Wróbel, J., Hutorowicz, A., 2012. Flora roślin wyższych jezior PNBT. In: Matuszkiewicz, J.M. (ed.) Świat roślin i grzybów Parku Narodowego „Bory Tucholskie”, Charzykowy, pp. 248-269. 
Kucharczyk, M., 2000. Charakterystyka chorologiczna wybranych gatunków roślin występujących na torfowiskach węglanowych koło Chełmna. In: Łętowski, J. (ed.) Walory przyrodnicze Chełmskiego Parku Krajobrazowego i jego okolic. UMCS Lublin, pp. 67-76.

Lansdown, R.V., Juffe Bignoli, D., Beentje, H.J., 2017. Cladium mariscus. The IUCN Red List of Threatened Species 2017: e.T164157A65910896. https://dx.doi.org/10.2305/IUCN.UK.2017-1.RLTS. T164157A65910896.en. Downloaded on 14 July 2021.

Latałowa, M., 1992. Man and vegetation in the pollen diagrams from Wolin Island (NW Poland). Acta Palaeobotanica 32(1), 123-149.

Maiz-Tome, L., 2016. Lobelia dortmanna. The IUCN Red List of Threatened Species 2016: e.T167831A78457082. https://dx.doi.org/10.2305/ IUCN.UK.2016-1.RLTS.T167831A78457082.en. Downloaded on 14 July 2021.

Marek, S., 1991. Studia nad stratygrafią torfowisk w Polsce. Wydawnictwo Uniwersytetu Wrocławskiego, Prace Botaniczne, XLVII.

Marszelewski, W., Prus, B., Błoniarz, W., Pestka, J., 2016. Stany wody w jeziorach PN „Bory Tucholskie“. In: Choiński, A., Kochanowska, M., Marszelewski, W. (eds) Przyroda abiotyczna Parku Narodowego „Bory Tucholskie”. Park Narodowy „Bory Tucholskie", Charzykowy, pp. 263-274.

Matuszkiewicz, J.M., Kozłowska, A., Solon, J., 2012. Land plant communities of National Park „Bory Tucholskie". In: Matuszkiewicz, J. (ed.) The world of plants and mushrooms of National Park "Bory Tucholskie”, BTNP, Charzykowy, pp. 63-138.

Meese, B., Morris, S., 1984. The sex life of flowers. Faber and Faber, London-Boston.

Milecka, K., 2005. Historia jezior lobeliowych zachodniej części Borów Tucholskich na tle postglacjalnego rozwoju szaty leśnej. Wyd. Nauk. UAM, Poznań, pp. 1-249.

Milecka, K., Obremska, M., 2002. Zawartość sporomorf Lobelia dortmanna i Isoëtes lacustris w najmłodszych warstwach osadów jeziora Nierybno. In: Banaszak, J., Tobolski, K. (ed.) Park Narodowy Bory Tucholskie na tle projektowanego rezerwatu biosfery. Park Narodowy Bory Tucholskie, Homini, Charzykowy, pp. 99-106.

Milecka, K., Tobolski, K., 2015. Cladium mariscus i Lobelia dortmanna - zagadkowe współwystępowanie w jeziorze Krzywce Wielkie. Studia Limnologica et Telmatologica 9, 37-48.

Milecka, K., Kupryjanowicz, M., Makohonienko, M., Nalepka, D., 2004. Quercus L. - Oak. In: RalskaJasiewiczowa, M., Latałowa, M., Wasylikowa, K. et al. (eds) Late Glacial and Holocene history of vegetation in Poland based on isopollen maps. W. Szafer Institute of Botany, Polish Academy of Sciences, Kraków: 189-197.

Miotk-Szpiganowicz, G., Zachowicz, J., Ralska-Jasiewiczowa, M., Nalepka, D., 2004. Corylus avellana L. - Hazel. In: Ralska-Jasiewiczowa, M.,
Latałowa, M., Wasylikowa, K. et al. (eds) Late Glacial and Holocene history of vegetation in Poland based on isopollen maps. W. Szafer Institute of Botany, Polish Academy of Sciences, Kraków: 79-87.

Moeller, R.E., 1978. Seasonal changes in biomass, tissue chemistry and net production of the evergreen hydrophyte Lobelia dortmanna. Canadian Journal of Botany 56, 1425-1433. https://doi.org/10.1139/ b78-165

Moen, A., 1999. National Atlas of Norway: Vegetation. Norwegian Mapping Authority, Hønefoss.

Mróz, W. (ed.) 2010. Monitoring siedlisk przyrodniczych. Przewodnik metodyczny. Biblioteka Monitoringu Środowiska, Warszawa.

Namura-Ochalska, A., 2004. Nowe, godne ochrony stanowisko Cladium mariscus (Cyperaceae) w północno-wschodniej Polsce. Fragmenta Floristica Geobotanica Polonica 11, 202-206.

Nienartowicz, A., 2012. History of forest of National Park „Tuchola Forest” and on adjoining areas. In: Matuszkiewicz, J. (ed.) The world of plants and mushrooms of National Park "Bory Tucholskie", BTNP, Charzykowy, pp. 47-62.

Odgaard, B.V., 1994. The Holocene vegetation history of northern West Jutland, Denmark. Opera Botanica 123, 5-171.

Pawłowska, S., 1972. Charakterystyka statystyczna i elementy flory polskiej. In: Szafer, W., Zarzycki, K. (eds) Szata roślinna Polski. PWN, Warszawa, pp. 129-206.

Pecl, G.T., Araújo, M.B., Bell, J.D., Blanchard, J., Bonebrake, T.C., Chen, I., Clark, T.D., Colwell, R.K., Danielsen, F., Evengård, B., Falconi, L., Ferrier, S., Frusher, S., Garcia, R.A., Griffis, R.G., Hobday, A.J., Janion-Scheepers, C., Jarzyna, M.A., Jennings, S., Lenoir, J., Linnetved, H.I., Martin, V.Y., McCormack, P.C., McDonald, J., Mitchell, N.J., Mustonen, T., Pandolfi, J.M., Pettorelli, N., Popova, E., Robinson, S.A., Scheffers, B.R., Shaw, J.D., Sorte, C.J.B., Strugnell, J.M., Sunday, J.M., Tuanmu, M.N., Vergés, A., Villanueva, C., Wernberg, T., Wapstra, E., Williams, S.E., 2017. Biodiversity redistribution under climate change: Impacts on ecosystems and human well-being. Science 355 , eaai9214. https://doi.org/10.1126/science.aai9214

Pełechaty, M., Pełechata, A., Pukacz, A., 2007. Flora i roślinność ramienicowa na tle stanu trofii jezior Pojezierza Lubuskiego (środkowo-zachodnia Polska). Bogucki Wydawnictwo Naukowe, Poznań, pp. 1-137.

Podbielkowski, Z., Tomaszewicz, H., 1994. Zarys hydrobotaniki. PWN, Warszawa.

Pokorny, P., Sadlo, J., Bernardova, A., 2010. Holocene history of Cladium mariscus (L.) Pohl in the Czech Republic. Implications for species population dynamics and palaeoecology. Acta Palaeobotanica $50,65-76$.

Poraj-Górska, A.I., Żarczyński, M.J., Ahrens, A., Enters, D., Weisbrodt, D., Tylmann, W., 2017. Impact of historical land use changes on lacustrine sedimentation recorded in varved sediments of Lake 
Jaczno, northeastern Poland. Catena 153, 182-193. https://doi.org/10.1016/j.catena.2017.02.007

$\mathrm{R}$ Core Team 2020. R: A language and environment for statistical computing. R Foundation Statistical Computing, Vienna, Austria. URL https://www.Rproject.org/.

Ralska-Jasiewiczowa, M., Latałowa, M., Wasylikowa, K., Tobolski, K., Madeyska, E., Wright, H.E., Turner, C. (eds) 2004. Late Glacial and Holocene history of vegetation in Poland based on isopollen maps. W. Szafer Institute of Botany, Polish Academy of Sciences, Kraków, pp. 1-444.

Reimer, P.J., Austin, W.E.N., Bard, E., Bayliss, A., Blackwell, P.G., Bronk Ramsey, C., Butzin, M., Cheng, H., Edwards, R.L., Friedrich, M., Grootes, P.M., Guilderson, T.P., Hajdas, I., Heaton, T.J., Hogg, A.G., Hughen, K.A., Kromer, B., Manning, S.W., Muscheler, R., Palmer, J. G., Pearson, C., van der Plicht, J., Reimer, R.W., Richards, D.A., Scott, E.M., Southon, J.R., Turney, C.S.M., Wacker, L., Adolphi, F., Büntgen, U., Capano, M., Fahrni, S.M., Fogtmann-Schulz, A., Friedrich, R., Köhler, P., Kudsk, S., Miyake, F., Olsen, J., Reinig, F., Sakamoto, M., Sookdeo, A., Talamo, S., 2020. The IntCal20 Northern Hemisphere Radiocarbon AgeCalibration Curve (0-55 cal ka BP). Radiocarbon 62(4), 725-757. https://doi.org/10.1017/RDC.2020.41

Ritchie, J.C., McHenry, J.R., 1990. Application of radioactive fallout cesium-137 for measuring soil erosion and sediment accumulation rates and patterns: a review. Journal of Environmental Quality 19, 215-233. https://doi.org/10.2134/ jeq1990.00472425001900020006x

Ronowski, R.P., Banaś, K., Merdalski, M., Szmeja, J., 2020. Plant replacement trend in soft-water lakes with isoetids. Oceanological and Hydrobiological Studies 49, 157-167. https://doi.org/10.1515/ohs2020-0015

Rothmaler, W., 1994. Exkursionsflora von Deutschalnd. Gefässpflanzen: Kritischer Band Gustav Fischer Verlag.

Rørslett, B., 1991. Principal determinants of aquatic macrophyte richness in northern European lakes. Aquatic Botany 39, 173-193. https://doi. org/10.1016/0304-3770(91)90031-Y

Rutkowski, L., 2004. Klucz do oznaczania roślin naczyniowych Polski niżowej. PWN, Warszawa.

Salmina, L., 2004. Factors influencing distribution of Cladium mariscus in Latvia. Annales Botannici Fennici 41, 367-371.

Sanchez-Cabeza, J.A., Ruiz-Fernández, A.C., 2012. ${ }^{210} \mathrm{~Pb}$ sediment radiochronology: An integrated formulation and classification of dating models. Geochimica et Cosmochimica Acta 82, 183-200. https:// doi.org/10.1016/j.gca.2010.12.024

Sand-Jensen, K., 1978. Metabolic adaptation and vertical zonation of Littorella uniflora (L.) Aschers. and Isoetes lacustris L. Aquatic Botany 4, 1-10. https://doi.org/10.1016/0304-3770(78)90002-5
Sand-Jensen, K., Borum, J., 1984. Epiphyte shading and its effect on photosynthesis and diel metabolism of Lobelia dortmanna L. the spring bloom in a Danish lake. Aquatic Botany 20, 109-119.

Sawilska, A.K., Dąbrowska, B., 1995. Kłoć wiechowata Cladium mariscus (L.) Pohl. na tle różnych warunków siedliskowych jezior Sztuczne i Zdręczno w Borach Tucholskich. Zeszyty naukowe ATR, Bydgoszcz, 190, Rolnictwo 36, 29-43.

Schubert, H., Blindow, I., Bueno, N.K., Casanova, M.T., Pełechaty, M., Pukacz, A., 2018. Ecology of charophytes - permanent pioneers and ecosystem engineers. Perspectives in Phycology 5, 61-74. https://doi.org/10.1127/pip/2018/0080

Sculthorpe, C.D., 1985. The Biology of Aquatic Vascular Plants. Edward Arnold (Publishers) Ltd. London.

Solon, J., Matuszkiewicz, J.M., 2012. Waloryzacja szaty PNBT, In: Matuszkiewicz, J.M. (ed.) Świat roślin i grzybów Parku Narodowego „Bory Tucholskie". Charzykowy.

Spence, D.H.N., 1982. The zonation of plants in freshwater lakes. Advances in Ecological Research 12, 37-125. https://doi.org/10.1016/ S0065-2504(08)60077-X

Subba Reddi, C., Reddi, N.S., 1986. Pollen production in some anemophilous angiosperms. Grana 25, 55-61. https://doi.org/10.1080/00173138609429933

Sugita, S., Gaillard, M.J., Broström, A., 1999. Landscape openness and pollen records: a simulation approach. The Holocene 9, 409-421.

Szczuciński, W., (submitted) Applications of gamma emitting isotopes $\left({ }^{210} \mathrm{~Pb}\right.$ and $\left.{ }^{137} \mathrm{Cs}\right)$ for assessment of sedimentary processes - insights from studies of lake, deltaic and continental shelf deposits.

Szmeja, J., 1987. The structure of a population of Lobelia dortmanna L. along a gradient of increasing depth in an oligotrophic lake. Aquatic Botany 28, 1-13.

Szmeja, J., 1992. Struktura, organizacja przestrzenna i demografia populacji isoetydów. Studium ekologiczne roślin podwodnych. UG, Gdańsk, pp. 1-129.

Szmeja, J., 1997. Specyfika i zagrożenia jezior lobeliowych. In: Fałtynowicz, W., Latałowa, M., Szmeja, J. (eds) Dynamika i ochrona roślinności Pomorza. Materiały z sympozjum 28-30 września 1995. Bogucki Wyd. Nauk. Gdańsk-Poznań, pp. 83-90.

Szmeja, J., 1998. Geneza, specyfika i zagrożenia jezior pomorskich. In: Herbich, J., Herbich, M. (ed.) Szata roślinna Pomorza. Zróżnicowanie, dynamika, zagrożenia, ochrona. Wyd. Uniwersytetu Gdańskiego, Gdańsk, 223-230.

Szmeja, J., 2014a. Lobelia dortmanna L. Lobelia jeziorna. In: Kaźmierczakowa, R., Zarzycki, K., Mirek, Z. (eds) Polish Red Book of Plants. Polish Academy of Sciences, Kraków, pp. 506-507.

Szmeja, J. 2014b. Isoëtes lacustris L. Poryblin jeziorny. In: Kaźmierczakowa, R., Zarzycki, K., Mirek, Z. (eds) Polish Red Book of Plants. Polish Academy of Sciences, Kraków, pp. 34-36. 
Szmeja, J., Bociąg, K., 2004. The disintegration of populations of underwater plants in soft water lakes enriched with acidic organic matter. Acta Societatis Botanicorum Poloniae 73, 165-173. https://doi. org/10.5586/asbp.2004.023

Szmeja, J., Bociąg, K., Banaś, K., 1998. Specyfika jezior lobeliowych w krajobrazie sandrowym Borów Tucholskich. In: Banaszak, J., Tobolski, K. (eds) Bory Tucholskie National Park. Stan poznania przyrody na tle kompleksu leśnego Bory Tucholskie. Akademia Bydgoska, Bydgoszcz, 171-191.

Tobolski, K., 1998. Stan poznania historii lasów, jezior i torfowisk Borów Tucholskich. In: Banaszak, J., Tobolski, K. (eds) Bory Tucholskie National Park. Stan poznania przyrody na tle kompleksu leśnego Bory Tucholskie. Akademia Bydgoska, Bydgoszcz, pp. 19-48.

Tobolski, K., 2003. Predyspozycje kontynentalne Niziny Wielkopolsko-Kujawskiej widziane przez Zygmunta Czubińskiego. In: Banaszak, J. (ed.) Stepowienie Wielkopolski. AB, Bydgoszcz, pp. 43-56.

Tobolski, K., 2006. Torfowiska Parku Narodowego „Bory Tucholskie”. Wydawnictwo BTPN, Charzykowy, pp. 1-174.

Tobolski, K., Gałka, M., 2008. Kopalne stanowisko kłoci wiechowatej (Cladium mariscus) w dolinie Brdy przy ujściu do jeziora Witoczno (Zaborski Park Krajobrazowy). Studia Limnologica et Telmatologica 2(1), 27-32.

Towpasz, K., Stachurska-Swakoń, A., 2009. Nowe stanowisko Cladium mariscus (Cyperaceae) w Polsce. Fragmenta Floristica et Geobotanica Polonica 16(1), 183-185.

Walker, M.J.C., Berkelhammer, M., Bj€orck, S., Cwynar, L.C., Fisher, D.A., Long, A.J., Lowe, J.J., Newnham, R.N., Rasmussen, N.O., Weiss, H., 2012.
Formal subdivision of the Holocene Series/Epoch: a discussion paper by a working group of INTIMATE (integration of ice-core, marine and terrestrial records) and the subcommission on quaternary stratigraphy (international commission on stratigraphy). Journal of Quaternary Science 27, 649-659. https://doi.org/10.18814/epiiugs/2018/018016

Woszczyk, M., Poręba, G., Malinowski, Ł., 2017. ${ }^{210} \mathrm{~Pb}$, ${ }^{137} \mathrm{Cs}$ and ${ }^{7} \mathrm{Be}$ in the sediments of coastal lakes on the Polish coast: Implications for sedimentary processes. Journal of Environmental Radioactivity 169-170, 174-185. https://doi.org/10.1016/j.jenvrad.2017.01.015

Woś, A., 1999. Klimat Polski. PWN, Warszawa: 1-302.

Wróbel, J., Hutorowicz, A. 2012. Flora of vascular plants of lakes in NPBT. In: Matuszkiewicz, J. (ed.) The world of plants and mushrooms of National Park "Bory Tucholskie", BTNP, Charzykowy, pp. 248-269.

Zarzycki, K., Szeląg, Z., 2006. Red list of the vascular plants in Poland. Instytut Botaniki W. Szafera, PAN, Kraków, pp. 1-14.

Zarzycki, K., Trzcińska-Tacik, H., Różański, W., Szeląg, Z., Wołek, J., Korzeniak, U., 2002. Ekologiczne liczby wskaźnikowe roślin naczyniowych Polski. Różnorodność biologiczna Polski, vol. 2. Instytut Botaniki W. Szafera, PAN, Kraków, pp. 1-183.

Zdanowski, B., 2004. Ogólna charakterystyka ekosystemów wodnych Parku Narodowego „Bory Tucholskie" In: Zdanowski, B., Hutorowicz, A., Białokoz, W. (eds) Ekosystemy wodne Parku Narodowego „Bory Tucholskie”. IRS, Olsztyn, pp. 7-14. 